\title{
NEWYYSBKHOOL
}

digitalcommons.nyls.edu

Faculty Scholarship

Articles \& Chapters

$2-1-2006$

\section{Evolving Understandings of American Federalism: Some Shifting Parameters}

Edward A. Purcell Jr.

New York Law School, edward.purcell@nyls.edu

Follow this and additional works at: http://digitalcommons.nyls.edu/fac_articles_chapters

\section{Recommended Citation}

50 N.Y.L. Sch. L. Rev. 3

This Article is brought to you for free and open access by the Faculty Scholarship at DigitalCommons@NYLS. It has been accepted for inclusion in Articles \& Chapters by an authorized administrator of DigitalCommons@NYLS. 


\title{
EVOLVING UNDERSTANDINGS OF AMERICAN FEDERALISM: SOME SHIFTING PARAMETERS
}

\author{
Edward A. Purcell, Jr.*
}

The generation that drafted and ratified the Constitution searched the past for wisdom and insight, and those who subsequently sought to understand their work often tried to follow their example. Through the decades students examined the founding era and then, inevitably, the lengthening list of contributions that later generations added in construing, implementing, and sometimes amending the founders' work. Together, those linked generations forged over the centuries an intricate, deeply embedded, and profoundly cherished tradition of democratic constitutionalism.

In studying their past, however, Americans learned that knowledge not only nourished their constitutional enterprise but also complicated it. Put simply, while history sometimes provided "lessons" or yielded "insights," it more commonly revealed disagreement, uncertainty, conflict, and change. In the years immediately following ratification, in fact, partisan strife tore the founders themselves into bitterly contending factions. The new nation "was beset by civil insurrections, secession threats, a quasi-war, foreign intrigue, and government repression," James Roger Sharp noted. ${ }^{1}$ "Even after a decade of government under the Constitution, George Washington was still unsure about the ultimate outcome."

* Joseph Solomon Distinguished Professor, New York Law School. The author would like to thank the members of the faculty colloquia at New York Law School and the University of Pennsylvania Law School and the members of the Legal History Colloquium at New York University Law School for their helpful comments on early drafts of this essay, especially Robert Blecker, William P. LaPiana, Denise C. Morgan, William E. Nelson, Catherine Struve, and Harry H. Wellington. He would also like to thank Lauren Borrone, Lisa Ornest, Susanna Roif, and Scott Woller for their invaluable assistance.

1. James Roger Sharp, American Politics in the Early Republic: The New NaTION IN CRISIS 2 (1993).

2. Id. "Less than a month before his death in 1799, [Washington] lamented that the critical political situation he had been observing 'with an anxious and painful eye' appeared 'to be moving by hasty strides to some awful crisis.'” Id. 
With particular intensity the founders struggled over the relationship between nation and states, a battle that inspired vigorous partisanship and resonated through every significant dispute that erupted. ${ }^{3}$ That issue, H. Jefferson Powell wrote, became the nation's "Oldest Question of Constitutional Law." ${ }^{4}$ After more than two hundred years, one might also term it the nation's "Most Enduring Question of Constitutional Law." ${ }^{5}$

There were numerous and complex reasons why American federalism proved so troublesome and contested, and in another work I hope to explore those reasons more fully. In this essay, however, I wish to consider only one of them - the fact that the federal structure created a flexible and dynamic system of government. With respect to that one reason, moreover, I wish to discuss only four evolutionary strains, moving from the more specific to the more general. Part I of this essay examines changes in ideas about the proper role of the Supreme Court in the federal system; Part II discusses changing ideas about the "values" of federalism; and Part III looks at shifts in our understanding of the nature of federalism as a structure of government. Finally, Part IV places those changes in the broader context of our evolving ideas about the nature and meaning of the Constitution itself.

3. Many of the Constitution's provisions carried relatively clear meanings or developed generally acceptable ones that became well-settled. There was no dispute, for example, that the Constitution established a central government with three distinct branches, ordained that each would have certain institutional characteristics and powers, and that each was subject to limitations. Equally, there was no dispute that the Constitution confirmed the existence of the states, made them constituent elements of the central government, and imposed specified limitations on their powers. The relative clarity of the Constitution's provisions dealing with institutional structures together with the acceptance of certain early practices and compromises allowed the new government to organize itself, begin operations, and establish over time a relatively stable institutional form. (1993)

4. H. Jefferson Powell, The Oldest Question of Constitutional Law, 79 VA. L. REv. 633

5. Ernest A. Young notes in exploring the doctrines of federalism that "the text and history of the Constitution yield few clear answers to federalism questions." Ernest A. Young, Making Federalism Doctrine: Fidelity, Institutional Competence, and Compensating Adjustments, 46 WM. \& Mary L. Rev. 1733, 1735 (2005). Peter Schuck adds a related complication. "All genuine federal systems are highly complex, contingent products of unique historical, social, and political forces." Peter H. Schuck, Citizenship in Federal Systems, 48 Ам. J. of Comp. L. 195, 198 (2000). 
The four parts point to an obvious, if quite preliminary, conclusion. Some of our most basic conceptions and assumptions about the federal system have changed substantially over the years. In analyzing American federalism, this essay suggests, we examine an evolving phenomenon through shifting analytical lenses, a fact that makes its study unusually difficult and its role as a constitutional norm highly questionable. This essay raises - though it does not purport to resolve - a fundamental theoretical question: whether, and to what extent, it is possible for "federalism" to serve as a meaningful and independent norm in the nation's constitutional enterprise. In other words, are the provisions of the Constitution that establish the federal structure, sufficiently clear, specific, and complete to direct those who construe them to "correct" decisions or, at least, to eliminate wide ranges of discretion in such decision making?

\section{Changing Ideas About the Role of the Supreme Court in THE Federal System}

Upon his election to the House of Representatives in 1789, James Madison considered the overwhelming challenges that lay ahead and admitted how little the Constitution had actually settled. "We are in a wilderness without a single footstep to guide us," he confessed. ${ }^{6}$ Of the many things the Constitution had not settled, the Supreme Court's role in dealing with conflicts between nation and states quickly soared toward the top of the list. The founding generation gave voice to a good many vague and conflicting ideas on the subject, but five were particularly noteworthy.

One was the view, sometimes termed "departmentalism," that the Court was only one of three federal branches, each of which was equally authorized to construe the Constitution in performing its duties. The Court's views could not override the constitutional judgments of either Congress or the executive, and unresolvable conflicts between the three, as well as conflicts, between nation and

6. Letter from James Madison to Thomas Jefferson (June 30, 1789), in 15 THE Papers of Thomas Jefferson 224 (Julian P. Boyd ed., 1985). Madison continued hopefully: "Our successors will have an easier task, and by degree the way will become smooth, short and certain." Id. 
states, could only be settled by the people themselves. ${ }^{7}$ Madison and Thomas Jefferson articulated the theory in the earliest years of the new government, while Presidents Andrew Jackson and Abraham Lincoln subsequently advanced their own versions in fighting the Court's definitions of national power. Jackson rejected the broad power that McCulloch v. Maryland ${ }^{8}$ upheld, while Lincoln castigated the narrow restrictions that Dred Scott v. Sandford ${ }^{9}$ imposed. Departmentalism remained a significant theory through the Civil War but faded during the late nineteenth century and reappeared only sporadically thereafter. ${ }^{10}$

A second view, associated most closely with Alexander Hamilton, ${ }^{11}$ maintained that the Court was required to construe the Constitution, that its decisions were to be authoritative, and that its oversight would ensure that both state and central governments stayed within their proper bounds. "The interpretation of the laws is the proper and peculiar province of the courts," Hamilton declared in the Seventy-Eighth Federalist. "A constitution is, in fact, and must be regarded by the judges, as a fundamental law." 12 The Philadelphia convention had produced "a limited Constitution" that "contains certain specified exceptions to the legislative authority," and those limitations "can be preserved in practice no other way than through the medium of courts of justice, whose duty it must be to declare all acts contrary to the manifest tenor of the Constitution void."13 Subsequently blessed by Chief Justice John Marshall's opinion in Marbury v. Madison, ${ }^{14}$ Hamilton's view gradu-

7. Larry Kramer, The People Themselves: Popular Constitutionalism and JuDicial Review, 105-14 (2004); Sharp, supra note 1, at 124-25, 130.

8. McCulloch v. Maryland, 17 U.S. (4 Wheat.) 316 (1819) (upholding the constitutionality of the second Bank of the United States).

9. Scott v. Sandford (Dred Scott), 60 U.S. (19 How.) 393 (1857) (declaring that Congress could not abolish slavery in the territories and that blacks could not become citizens of the United States).

10. See generally KRAMER, supra note 7 .

11. Others advanced similar views. E.g., James Wilson, Speech in the Pennsylvania Ratifying Convention (1888), in 2 Debates on the Adoption of the Federal ConstituTION 415, 445-46, 489 (Jonathan Elliot ed., 1987).

12. The Federalist No. 78, at 506 (Alexander Hamilton) (The Modern Library 1941).

13. Id. at 505. Accord The Federalist No. 22, supra note 12, at 138-39 (Alexander Hamilton).

14. Marbury v. Madison, 5 U.S. (1 Cranch) 137 (1803). 
ally gathered support, especially after the Civil War, and helped legitimize the power of judicial review and underwrite the Supreme Court's growing authority from the late nineteenth century onward. ${ }^{15}$

A third view came from the Anti-Federalists and was advanced most forcefully by a particularly able pamphleteer known only as "Brutus."16 Agreeing with Hamilton that the Court would be the authoritative voice of the Constitution, ${ }^{17}$ Brutus maintained that the result would be both biased and disastrous. Because the Court was an integral part of the national government, he predicted, it "will lean strongly in favour of the general government, and will give such an explanation to the constitution, as will favour an extension of its jurisdiction." 18 Thus, the Constitution was dangerous precisely because Hamilton was right about the role the Court would play but wrong about the way it would exercise its power. "The judicial power will operate to effect, in the most certain, but yet silent and imperceptible manner, what is evidently the tendency of the constitution," Brutus charged: "I mean, an entire subversion

15. Ideas about judicial review evolved in a slow and complicated manner, and the practice of judicial review changed substantially over the years. "Not until the late nineteenth century did the Supreme Court cite the Marbury decision as precedent for judicial review, and only in 1910 did the distinguished historian of the judiciary Edward Corwin actually coin the term 'judicial review." Gordon S. Wood, The Origins of Judicial Review Revisited, or How the Marshall Court Made More out of Less, 56 WASH. \& LeE L. Rev. 787, 788-89 (1999). See, e.g., Robert A. Burt, The Constitution in Conflict (1992); Kramer, supra note 7; William E. Nelson, Marbury v. Madison: The Origins and Legacy of Judicial Review (2000); Sylvia Snowiss, Judicial Review and the Law of the Constitution (1990); Christopher Wolfe, The Rise of Modern Judicial Review: From Constitutional Interpretation to Judge-Made Law 73-84 (1986); Matthew D. Alder \& Michael C. Dorf, Marbury v. Madison: A Bicentennial Symposium, 89 VA. L. Rev. 1105 (2003).

16. The identity of "Brutus" is disputed. His essays were published in New York and are not to be confused with a much briefer contribution from another "Brutus" who wrote in Virginia. See Essays of Brutus, in 2 The Complete Anti-Federalist 358 (Herbert J. Storing ed., 1981).

17. " $[\mathrm{T}]$ he supreme court has the power, in the last resort, to determine all questions that may arise in the course of legal discussion, on the meaning and construction of the constitution." Essays of Brutus, No. XI, supra note 16, at 423. In addition the judiciary article of the Constitution "is so modelled, as to authorise the courts, not only to carry into execution the powers expressly given, but where these are wanting or ambiguously expressed, to supply what is wanting by their own decisions." Essays of Brutus, No. XII, supra note 16 , at $417,418$.

18. Essays of Brutus, No. XI, supra note 16, at 417, 420. 
of the legislative, executive, and judicial powers of the individual states." 19 His warning sounded ominously during the ratification debates, reverberated loudly through the ante-bellum years, and continued to echo periodically into the twenty-first century. ${ }^{20}$

The fourth view emerged in the 1790s and came to dominate the Federalist Party by decade's end. The proper role of the Supreme Court, and the federal judiciary in general, most "later Federalists" ${ }^{21}$ came to believe, was to protect the strong central government the Constitution had established by ensuring that it remained in the hands of its true adherents. Convinced that they were the virtuous and authentic party of the Constitution, the later Federalists "could not picture themselves as an 'alternative' to anything." 22 Thus, as their hold on power began to slip after Washington's presidency, they "imagined themselves in a state of siege," 23 established and then expanded a provisional army, ${ }^{24}$ enacted the oppressive Alien and Sedition Acts, and turned to the National judi-

19. Id

20. E.g. Robert H. Bork, The Tempting of America: The Political Seduction of THE LAw 129 (1990) ("From first to last the Court has been a strong force for centralization in our national life,"); Robert F. Nagel, The Implosion of American Federalism 11 (2001) (“[T]he Court's place in our governmental structure and, even more importantly, its intellectual and professional dispositions disqualify the justices from any significant part in nurturing a strong form of federalism.”).

21. I use the phrases "later Federalists" and "Federalist Party" to distinguish those in the late 1790s who supported the Alien and Sedition Acts and other related party measures from those who called themselves "Federalists" during and shortly after the ratification debates.

22. Stanley Elkins \& Eric McKitrick, The Age of Federalism 693, 703 (1993). The Republicans shared many of the attitudes that marked the Federalists, including their hostility to parties and their belief that men of "virtue" should govern. However, their social bases and oppositional stance led them toward relatively more flexible and tolerant views. See, e.g., SHARP, supra note 1, at 135-36, 157-59, 187-88, 192-94, 216-17, 231-32, 273-74, 276; Joanne B. Freeman, Explaining the Unexplainable: The Cultural Context of the Sedition Act, in The Democratic Experiment: New Directions in American Political History 20, 20-49 (Meg Jacobs, William J. Novak, \& Julian E. Zelizer eds., 2003).

23. ElKins \& McKitrick, supra note 22, at 693.

24. In 1797 and 1798, war with France threatened and many Federalists sought to use the situation to establish a national army that could intimidate their political opponents and possibly even invade the South, the stronghold of anti-Federalist Republicanism. See Stephen G. Kurtz, The Presidency of John Adams: The Collapse of Federalism, 1795-1800, at 307-33 (1957). 
ciary - packed with Federalist appointees ${ }^{25}$ - to enforce the laws and thereby intimidate their opponents. ${ }^{26}$ During the next two years, they made a concerted effort to ensure victory in the presidential election of 1800 by charging some two dozen Republican activists with seditious libel, indicting seventeen of them, and convicting ten. Not one Federalist judge questioned the constitutionality of the repressive measures, and the Supreme Court did not review a single conviction. ${ }^{27}$ Indeed, all the Federalist judges who heard prosecutions treated the statutes favorably, ${ }^{28}$ and two Supreme Court justices - William Patterson and Samuel Chase presided over successful Sedition Act prosecutions while making their Federalist political sympathies glaringly apparent. ${ }^{29}$ Finally, when they lost the election, the Federalists used their lame-duck control of Congress and the executive branch to expand the jurisdiction of the federal judiciary and pack more Federalists onto the bench. Upon taking power, the Jeffersonian Republicans repealed the measures and attempted to impeach the most unrestrained Federalist judges. ${ }^{30}$ Thus, despite the fact that many of the founders including Hamilton, Patterson, John Adams, and perhaps both

25. Even before the Federalists enacted the Alien and Sedition Acts, a federal judge had initiated a prosecution against a Republican member of the House, Samuel J. Cabell of Virginia, for publishing "unfounded calumnies against the happy government of the United States." Sharp, supra note 1, at 169 (1993).

26. "The main reason the 1790s witnessed a decisive change in American political culture is that there was something fundamental to decide. We can detect this in the behavior of the Federalists. They exuded the confidence of men whose view reflected deeply ingrained ways of thinking about politics. When public discourse turned polemical their voices became shrill, but they never lost their posture of protecting known truths about civil society. They knew that it was their opponents who were treading unfamiliar paths and they appealed to history and common sense to prove them wild visionaries." Joyce Appleby, Capitalism and a New Social Order: The Republican VISION OF THE 1790s 5-6 (1984). See id. at 5-14, 58-61, 66-67, 75-77, 79-80, 93-94.

27. Because the Court was composed entirely of Federalist judges, none of those convicted sought review. Geoffrey R. Stone, Perilous Times: Free Speech in Wartime 47-48, 63, $68 \&$ n.† (2004).

28. The unanimity and vigor of the Federalist judges was particularly striking because the Sedition Act facially restricted political speech, and the First Amendment stated: "Congress shall make no law ... abridging the freedom of speech or the press." U.S. CONST. amend I.

29. James F. Simon, What Kind of Nation: Thomas Jefferson, John Marshall, and the Epic Struggle to Create a United States 53-55 (2002).

30. See Richard E. Ellis, The Jeffersonian Crisis: Courts and Politics in the Young Republic (New York, 1971); Simon, supra note 29, at 147-48. 
Washington and Marshall ${ }^{31}$ - accepted the later Federalist view, the election of 1800 and the political developments that followed wholly discredited it. By 1815 the Federalist Party had disappeared from national politics, and their view of the Court's role seemed to most Americans as antithetical to the very idea of constitutional government. ${ }^{32}$

Finally, the fifth view was articulated most famously by Jefferson and Madison in the Virginia and Kentucky Resolutions of 1798. Rallying opposition to the Federalist repression, they maintained that in constitutional disputes the Court's role was subordinate and that the states were the primary institutions responsible for ensuring that the national government remained cabined within its delegated sphere. ${ }^{33}$ Because the federal judiciary could usurp

31. Hamilton, Patterson, and Washington all participated in the Philadelphia Convention; Marshall was a major advocate of the Constitution in the Virginia ratifying convention; and Adams - serving during the drafting and ratification of the Constitution as the nation's envoy to Great Britain - published at the time an elaborate threevolume treatise that defended the basic principles the framers adopted in the Constitution. While the support of Hamilton, Patterson, and Adams for the Alien and Sedition Acts was manifest, the position of Washington and Marshall was less certain. Washington played no active role involving the acts, but he seemed to lend his support to them by privately conveying his views that some newspapers had long deserved punishment for their criticisms of Federalist leaders. David McCullough, John Adams, 506 (2001). Marshall tried to avoid taking a firm public stand while running for Congress in 1798. His opponent challenged the constitutionality of the acts, but Marshall refused to do so. Simon, supra note 29, at 56; R. Kent Newmyer, John Marshall and the Heroic Age of the Supreme Court 122-26, 172 n.39 (2001). Jean Edward Smith, John Marshall: Definer of A NAtion 239, 263 (1996), suggests that, at some later point, Marshall did develop constitutional doubts about the statutes.

32. What the nation rejected was the principle that the Court should protect a specific political party as the "true" defender of the Constitution by upholding the party's use of national power to maintain its control over the national government.

33. In the Virginia Resolutions, Madison invoked the compact theory, declared the states "duty bound" to "interpose" themselves against unconstitutional acts, and appealed to the other states to "concur with this Commonwealth" in declaring the Federalist statutes void. See Resolutions as Adopted by Both Houses of Assembly, Resolutions of Virginia of December 21, 1798, and Debate Thereon, in The Virginia Report of 1799-1800, Touching the Alien and Sedition Laws; Together with the Virginia Resolutions of December 21, 1798, 22, 22-23, paras. 3, 7 (Leonard W. Levy ed., Da Capo Press 1970) (1850). In the more radical Kentucky Resolutions, Jefferson also invoked the compact theory and announced that each party to the agreement "has an equal right to judge for itself" on matters of constitutionality, but he went beyond Madison and directly pronounced the statutes "not law" and "altogether void and of no force.” Resolutions of Kentucky Legislature, In the House of Representatives, NoVEMBER 10Th, 1798, in The Virginia REPORT OF 1799-1800, supra note 33 , at 162, 162-64, 
"dangerous powers, not delegated," the resolutions of the Virginia legislature proclaimed, the states necessarily retained "the ultimate right" as parties to the Constitution "to judge whether the compact has been dangerously violated." 34 Those ideas were subsequently developed by a long line of ante-bellum southern spokesmen, and they underwrote the hard-line states' rights position that remained vital until the Civil War and continued even thereafter to attract scattered adherents, especially among those adamantly opposed to the dominant policies of the national government.

Although the five views were distinct, they were also frequently intermixed in the minds of the founders. Madison and Jefferson, for example, reflected the embryonic nature of the founders' ideas about federalism and the Court. At different times both not only articulated "departmentalist" as well as "states' rights" ideas, but each on occasion also advanced ideas that sounded quite "Hamiltonian." In the Federalist Madison argued that the Supreme Court was to be the authoritative voice in drawing the line between federal and state power. "It is true that in controversies relating to the boundary between the two jurisdictions," he declared, "the tribunal which is ultimately to decide, is to be established under the

paras. 1, 4. The resolutions declared the Federalist statutes unconstitutional in slightly varying terms, and the quotations in the text are drawn from the language addressed specifically to the Alien Act.

As a general matter, Madison's views were more tentative and balanced than Jefferson's. In The Federalist papers, Madison had suggested that the Court would police the boundary between states and nation. See The Federalist No. 39, supra note 12, at 249 (James Madison). He subsequently reiterated that position as president. See, e.g., James Madison, Veto Message, March 3, 1817 in 2 Messages and Papers of the Presidents 569, 570 (1897). Perhaps most striking, during the South Carolina tariff crisis between 1828 and 1833, the aged Madison rejected the doctrine of state nullification and upheld the supremacy of national law and the final authority of the Supreme Court over matters of constitutional interpretation. See Ralph Ketcham, James Madison: A Biography 640-46 (1990). For a complex and subtle analysis of Madison's position, see Drew R. McCor, The Last of the Fathers: James Madison \& The Republican Legacy 119-70 (1989).

34. Report of 1799, Virginia, in The Virginia Report of 1799-1800, Touching the Alien and Sedition Laws; supra note 33, at 186, 196. "On any other hypothesis, the delegation of judicial power would annul the authority delegating it; and the concurrence of this department with the others in usurped powers might subvert for ever, and beyond the possible reach of any rightful remedy, the very Constitution which all were instituted to preserve." Id. Madison argued that the people of the sovereign states had formed the central government and "that there can be no tribunal above their authority, to decide in the last resort, whether the compact made by them be violated." Id. at 192. 
general government." 35 Similarly, in 1787 Jefferson agreed that there should be "an appeal from the state judicature to a federal court" to settle "all cases where the act of Confederation controuled," and the following year he praised the idea of federal judicial review as a protector of constitutional rights. ${ }^{36}$ After ratification, warning against the dangers of legislative and executive tyranny, he urged adoption of a bill of rights because of "the legal check which it puts into the hands of the judiciary." 37 Conversely, even Hamilton himself did not always sound "Hamiltonian," affirming in the Federalist a distinctly "Jeffersonian" proposition. "It may safely be received as an axiom in our political system, that the State governments will, in all possible contingencies, afford complete security against invasions of the public liberty by the national authority," the arch-nationalist wrote. State legislatures "can discover the danger at a distance; and possessing all the organs of civil power, and the confidence of the people, they can at once adopt a regular plan of opposition, in which they can combine all the resources of the community." 38 Whether the argument reflected Hamilton's actual expectations or merely his tactical shrewdness, it exemplified the founding generation's deep uncertainty as to how the new federal system would and should operate. ${ }^{39}$

As debate over the nature of the federal system intensified in the ante-bellum years, rival positions coalesced, grew familiar, and

35. The Federalist No. 39, supra note 12, at 249 (James Madison). He continued: "Some such tribunal is clearly essential to prevent an appeal to the sword and a dissolution of the compact; and that it ought to be established under the general rather than under the local governments, or, to speak more properly, that it could be safely established under the first alone, is a position not likely to be combated." Id.

36. Letter from Thomas Jefferson to James Madison (June 20, 1787), in 10 THE Papers of James Madison 64 (Robert A. Rutland et al. eds., 1977); Letter from Thomas Jefferson to James Madison (Oct. 17, 1788), in 11 Papers of Thomas Jefferson 659 (Julian Boyd ed., 1958). On the evolution of Jefferson's politics, see R.B. BERnSTEIN, THOMAS JEFFERSON 55-134 (2003).

37. Letter from Thomas Jefferson to James Madison (March 15, 1789), in 12 PAPERS OF JAMES MADISON supra note 36 , at 14-15.

38. The Federalist, No. 28, supra note 12, at 174 (Alexander Hamilton).

39. As late as 1798 , for example, John Marshall "had not yet fully formulated his theory, set forth in Marbury, that constitutional questions of a legal nature were the exclusive prerogative of the Supreme Court." Newmyer, supra note 31, 103 (2001). For insightful accounts of differences between the views of Madison and Hamilton on judicial review, see Burt, surpa note 15; Sheldon S. Wolin, The Presence of the Past: Essays on the State and the Constitution, 109-19 (1989). 
began to rigidify along sectional lines. While the "later" Federalist view disappeared, the other four evolved and remained in relatively continuous use. Hamilton's ideas grew increasingly prominent in the North, while departmentalism, the arguments of Brutus, and the nullificationist ideas espoused in the Virginia and Kentucky Resolutions blended into a variety of anti-Court and "states' rights" positions that the South increasingly embraced with fervor. ${ }^{40}$ By 1819 when Spencer Roane, a judge on the Virginia Court of Appeals, attacked Marshall's nationalist opinion in McCulloch v. Maryland, he was readily able to draw on a full reservoir of arguments and quotes from a range of commentators - including Brutus, Madison, Jefferson, and even Hamilton himself - to defend the contention that "the ultimate redress against unconstitutional acts of the general government" lay with the "state legislatures" which would "sound the alarm to the people, and effect a change." In any event, Roane insisted, "the judiciary is not, in such cases, a competent tribunal." ${ }^{41}$

By the 1820s and 1830s Southerners and their supporters bluntly rejected the idea that the Court was the ultimate arbiter of federalism disputes. Determinations about the scope of governmental powers "were not intended to be surrendered to six men," John Taylor of Caroline protested, for "the universal idea of judicial power confined its operation to individuals, and had never extended it to political departments." ${ }_{2}$ The Court's power "may, without control, disorder and subvert the primary division of power" in the federal system and become a "gradual and piecemeal mode of destroying it." 43 As the sectional split widened, Southern theorists blended older ideas into a sweeping assault on the national judiciary. Federal judges were merely "the judicial represent-

40. Although the ante-bellum states-rights advocates appealed to Jefferson and Madison, neither of those two founders seriously advocated secession. See, e.g., Letter from Thomas Jefferson to John Taylor (June 1, 1798), in 7 The Writings of Thomas JefFerson 263, 263-66 (Paul Leicester Ford ed., 1896) [hereinafter 7 The Writings of Thomas Jefrerson]; Letter from Jefferson to Elbridge Gerry (May 13, 1797), in 7 The Writings of ThOMAs JefFerson, supra note 40, at 122-23; supra text accompanying note 35 (discussing Madison's position).

41. Spencer Roane, Hampden, Essay No. 4, in John Marshall's Defense of McCulloch v. Maryland 147, 148 (Gerald Gunther ed., 1969) (emphasis in original). (1822).

42. John Taylor, Tyranny Unmasked 203-04 (F. Thornton Miller ed., 1992)

43. TAYLOR, supra note 42, at 203, 207, 211. 
atives"of a "united majority," John C. Calhoun charged, and granting them power to determine the constitutionality of laws "would be, in reality, to confide it to the majority, whose agents they are." ${ }_{44}$ Thus, "it would seem impossible to deny to the States the right of deciding on the infractions of their powers," for the "right of judging, in such cases, is an essential attribute of sovereignty." 45

In his famous debate with Daniel Webster in 1830, Senator Robert Y. Hayne of South Carolina etched the states' rights position sharply. ${ }^{46}$ "It is clear that questions of sovereignty are not the proper subjects of judicial investigation," he maintained. "They are much too large, and of too delicate a nature, to be brought within the jurisdiction of a Court of justice." 47 As the United States Supreme Court had never assumed jurisdiction over questions arising under international treaties between "sovereigns," the Court could not "assume jurisdiction over questions arising between the individual States and the United States." Echoing Brutus, Hayne insisted that the Court was inherently "disqualified from assuming the umpirage between the States and the United States, because it is created by, and is indeed merely one of the departments of the Federal Government." 48

In opposition, ardent nationalists - drawn increasingly from the North and West - rejected the states' rights position and drew on Hamilton and Marshall to defend the Court's role as the ultimate constitutional authority. Justice Joseph Story made Herculean efforts as both scholar and justice to counter Southern arguments and develop a nationalist jurisprudence that placed a vibrant fed-

44. John C. Calhoun, The Fort Hill Address, in Union and Liberty: The Political Philosophy of John C. Calhoun 367, 380 (Ross M. Lence ed., 1992) (1831).

45. John C. Calhoun, Exposition and Protest, in Union and Liberty: The Political Philosophy of John C. Calhoun, supra note 45, at 348.

46. For discussion of the Webster-Hayne Debate, see Robert V. Rimini, Daniel Webster: The Man and His Time 312-31 (1997).

47. Speech of Robert Y. Hayne of South Carolina (Jan. 27, 1830), in The WebsterHayne Debate on the Nature of the Union: Selected Documents 169 (Herman Belz ed., 2000) [hereinafter Hayne, in The Webster-Hayne Debate] (emphasis in original). Also responding to Webster, Senator Thomas Hart Benton of Missouri charged that making the Court the final arbiter of the Constitution gave it "despotic" power and promised the "annihilation of the States." Speech of Thomas Hart Benton of Missouri (Jan. 20 and 29, Feb. 1 and 2, 1830), in The Webster-Hayne Debate, supra note 47, at 235.

48. Hayne, in The Webster-Hayne Debate, supra note 47, at 170. 
eral judicial power at the center of the constitutional system. ${ }^{49}$ There was "a final and common arbiter provided by the constitution itself, to whose decisions all others are subordinate," he insisted; "and that arbiter is the supreme judicial authority of the courts of the Union."50 Replying to Hayne on the Senate floor, Webster gave the nationalist theory its most famous and eloquent voice, identifying the South with nullification and the North with Union and the Court. By creating the federal judicial power and mandating the supremacy of federal law, Webster thundered, the Constitution created "the key-stone of the arch" and mandated that "all questions of constitutional power" be resolved by "the final decision of the Supreme Court." 51

Webster's powerful defense of the Court did more than embrace and extend the Hamiltonian view. It also illustrated the fluid and dynamic nature of ideas about the Court and its role in the federal system. His oration was, in fact, inspired by more than the goal of identifying New England with union and the South with division. It also sought to achieve a further purpose, to erase from national memory New England's own ill-fated invocation of "state sovereignty" and secessionism during the War of 1812 and the disastrous Hartford Convention. ${ }^{52}$

Only the Civil War could begin to settle those original debates. Northern victory determined that states could not secede, nullify federal law, or act as final authorities in construing the Constitution. Repudiated by Union victory, rejected by the Court, and then

49. R. Kent Newmyer, Supreme Court Justice Joseph Story: Statesman of the Old Republic 95, 99, 109, 114, 188, 191, 193, 256 (1985).

50. 1 Joseph Story, Commentaries on the Constitution of the United States 347 (1833).

51. Speech of Daniel Webster, of Massachusetts (Jan. 26 and 27, 1830), in THE Webster-Hayne Debate, supra note 47, at 137. The Constitution itself, Webster argued, made it clear that all questions dealing with the powers of states and nation "must be decided by the Judicial Tribunals of the United States." Id. at 132.

52. Herman Belz, Foreword to in The Webster-Hayne Debate, supra note 47, at xii. See also James M. Banner, Jr., To the Hartford Convention: The Federalists and the Origins of Party Politics in Massachusetts, 1789-1815 (1970). Some New England and northern states would again raise the banner of states' rights and nullification before the Civil War as part of their efforts to combat Southern political power and enforcement of the federal fugitive slave laws. See Thomas D. Morris, Free Men All: The Personal Liberty Laws of the North 1780-1761 (1974); Stanley W. Campbell, The Slave Catchers: Enforcement of the Fugitive Slave Law 1850-1860 (1970). 
effectively buried by a century and a half of national history, the extreme Southern states' rights position withered and disappeared as a viable constitutional theory, surfacing in later decades for the most part only as a last-ditch justification for racism and legalized racial discrimination. ${ }^{53}$

As Hamilton's view grew into orthodoxy in the post-Civil War decades, some constitutional thinkers began to turn toward the Court as the new defender-by-default of the states and the federal system. Thomas M. Cooley, perhaps the most influential constitutional theorist of the late nineteenth century, acknowledged the change the war had wrought. The "effectual checks upon the encroachments of federal upon state power must be looked for, not in state power of resistance" he wrote, but in the federal electoral process and "in a federal supreme court with competent power to restrain all departments and all officers within the limits of their just authority." 54 It was "quite evident" that the national courts were "the only effectual balance-wheel of the whole system," Woodrow Wilson, then a young political scientist, declared a few years later. ${ }^{55}$ "The federal judges hold in their hands the fate of state powers, and theirs is the only authority that can draw effective rein on the career of Congress." 56 While Americans had long portrayed the Constitution as the nation's "anchor," they began in the late nineteenth century to shift their focus, conferring that high metaphori-

53. The theory was vigorously revived, for example, in the wake of Brown $v$. Board of Education. See 347 U.S. 483 (1954); see, e.g., James Jackson Kilpatrick, The Sovereign States: Notes of a Citizen of Virginia (1957). The significance of race and its driving power behind the constitutional theory was readily apparent. On one single page, for example, Kilpatrick made, inter alia, the following statements: "The Negro race, as a race, has palpably different social, moral, and behavioral standards from those which obtain among the white race. . . That necessary program of the professional welfare worker, styled 'aid to dependent children,' is very largely aid to Negro bastardy. . . . In areas where Negroes make up less than one-third of the population, colored patients account for 90 per cent of all reported syphilis and gonorrhea. . . The undisciplined passions which find one outlet in sex find another in crime." Id. at 279.

54. Thomas M. Cooley, General Principles of Constitutional Law in the United States of America 143-44 (1880).

55. Woodrow Wilson, Congressional Government: A Study in American PolitICS 33-34 (1885).

56. Id. Two decades later Wilson put the matter in terms of constitutional necessity. "The whole balance of our federal system, therefore, lies in the federal courts," he announced. "It is inevitable that it should be." Woodrow Wilson, Constitutional Government in the United States 157 (Transaction Publishers 2002) (1908). 
cal honor directly on the Court itself. Chief Justice Morrison Waite recognized the change. "The Court," he announced, "is now looked upon as the sheet anchor." ${ }^{5}$ Two decades later Justice David J. Brewer spoke a commonplace, at least among the nation's conservative elements, when he identified the Court simply as "The Nation's Anchor." 58 Thus, the idea that the Court was the constitutional defender of the states emerged into national prominence only as a product of the Civil War, the massive and disruptive social changes that followed, and the gradual rise of the Court to an ever more powerful position in an industrializing and centralizing nation. For states'-rights advocates, it was a belated, fall-back expedient, one thrust on them by military defeat and harsh necessity.

The emerging post-Civil War view of the Court's role stood in sharp contrast to most of the views that the founders had advanced, and it differed significantly even from Hamilton's, the one it most closely resembled. First, Hamilton and the Federalists of 1787-89 believed that the national courts were necessary not to protect the states but to protect the new central government. They believed, further, that the national courts were necessary for the precise purpose of protecting that new central government from the likely defiance and subversion of the states. ${ }^{59}$ In the original Hamiltonian view, then, the Court's role in the federal system was the opposite of the one that came to be commonly attributed to it in the late nineteenth century. Second, the early Federalists saw the Senate, not the judiciary, as the national institution specifically designed to safeguard the states and guarantee their sovereignty. The equal vote of each state in the Senate, the Federalist declared, was "a constitutional recognition of the portion of sovereignty remaining in the individual States, and an instrument for preserving that residuary sovereignty."60 Another Federalist pamphleteer put the point more bluntly. "The federal Senate," he maintained, "are the representatives

57. Quoted in Michael Kammen, A Machine That Would Go Of Itself: The Constitution in American Culture 17 (1986).

58. David J. Brewer, The Nation's Anchor, 57 Albany L.J. 166 (1898).

59. See Jack N. Rakove, The Origins of Judicial Review: A Plea for New Contexts, 49 Stan. L. Rev. 1031, 1041-50 (1997).

60. The Federalist No. 62, supra note 12, at 402 (Alexander Hamilton or James Madison). 
of the sovereignties of their respective states." 61 Thus, when Americans in the late nineteenth century began to conceive of the Court as the protector of the states, they drew on but one of many variant theories that the founders had advanced; and, equally purposefully, they substantially reshaped the particular theory they selected for use.

There also was an embarrassing triple irony in the spreading post-Civil War view that the Court was the protector of the states. First, the idea resonated awkwardly with the Court's infamous decision in Dred Scott v. Sanford. ${ }^{62}$ In the ante-bellum context marked by explosive population growth in the North and an intensifying sectional conflict over slavery, the Constitution's provision for admitting new states had transformed the Senate from the protector of the states generally into the protector of the slave states in particular. ${ }^{63}$ Fearing that it would be unable to control the presidency and the House of Representatives, the South clung tenaciously to its equality in the Senate. For decades it insisted on the admission of a new slave state to balance each newly admitted free state. Then, when the balance stood at fifteen apiece, Congress attempted to resolve the escalating sectional dispute with the desperate Compromise of 1850, one element of which admitted California as a free

61. Tench Coxe, A Democratic Federalist, in Friends of the Constitution: Writings OF THE "Other" Federalists, 1787-1788, at 352 (Colleen A. Sheehan \& Gary L. McDowell eds., 1998) [hereinafter in Friends of the Constitution]. James Wilson made the same point, insisting that the "existence of the state governments is one of the most prominent features" of the Constitution and that the power of state legislatures to elect Senators guaranteed the states a major role in the new government. "[I]f a state legislature is not elected," he declared, "there can be no Senate." James Wilson, speech in the Pennsylvania Ratifying Convention, in 2 Debates on the Adoption of THE FedERAl Constitution 415, 461 (Jonathan Elliot ed., 1987) (1888). Similarly, other Federalist pamphlets emphasized that "an entire representative body was assigned to the state legislatures, called the Senate," $i d$. at 257, 262, and that "the construction of the senate affords an absolute certainty, that the states will not lose their present share of separate powers." Tench Coxe, A Freeman, in Friends of the Constitution, supra note 61, at 99. As part of his states' right argument against the power of the Supreme Court, Spencer Roane pointed to the founders' idea that the Senate, not the Court, was to be a protector of the states. See Roane, supra note 42, at 144-46.

62. See 60 U.S. 393 (1857).

63. Ante-bellum Southerners agreed in principle with the original conception of the Senate. See John C. Calhoun, A Discourse on the Constitution and Government of the United States, in Union and Liberty: The Political Philosophy of John C. Calhoun 79, 125 (Ross M. Lence ed., 1992); St. George Tucker, View of the Constitution of the United States with Selected Writings 98 (Clyde N. Wilson ed., 1999) (1803); Roane, supra note 42 , at $144-46$. 
state and ended forever the equality of the slave states in the Senate. Quickly, the South turned from relying on a Senate veto to advancing an audacious constitutional argument that made slavery a national institution and compelled the federal government to protect its existence everywhere in the Union and its territories. In 1857 the Supreme Court outraged the North by its decision in Dred $S c o t t$, where it held that the plaintiff remained a slave even in a free state and adopted - at least in the sweeping opinion of Chief Justice Roger B. Taney — the South's aggressive pro-slavery constitutional theory. ${ }^{64}$ At that crucial point, the Court suddenly made itself the defender of slavery and the South. Thus, it was Dred Scott that made it plausible for even the most recalcitrant post-war white Southerner to think that the Court could function as the protector of the states and their rights.

Second, the war changed the law radically by inspiring three sweeping constitutional amendments that imposed severe new limitations on the states and added substantially to the powers of Congress. These amendments gave the states no new constitutional basis for claiming special protection from the Court, and they suggested no special role for the Court in either protecting the states or in limiting Congress. Indeed, as late as 1880 the Court declared that the federal courts, absent congressional authorization, lacked power to enforce the Fourteenth Amendment. "It is not said," the justices reasoned in Ex parte Virginia, "that the judicial power of the general government shall extend to enforcing the prohibitions and to protecting the rights and immunities guaranteed."65 Thus, the new role of the Court as the defender of the states was not authorized by the Civil War amendments. To the contrary, the role seemed oblique to, if not inconsistent with, their language and purpose.

Third, the three Civil War amendments were intended to protect the freed slaves and to guarantee them liberty, equality, and the

64. Each of the justices wrote separately in the case. On the politics of the $1840 \mathrm{~s}$ and 1850s and the complexities of the Court's decision, see the excellent study by Don E. Fehrenbacher, The Dred Scott Case: Its Significance in American Law \& Politics (1978).

65. Ex parte Virginia, 100 U.S. 339, 345 (1880) (emphasis in original). 
rights of national citizenship. ${ }^{66}$ Yet, as the Court began to construe them, it constrained their meaning stringently and in the process sacrificed the values and purposes that had inspired them. After Reconstruction, when the Court began to emerge as the de facto protector of the states, it did so by effectually condoning the concerted and violent efforts of the Southern states to disenfranchise, segregate, and oppress their black citizens. ${ }^{67}$ The Court's role as protector of the states, in other words, was not only unauthorized by the three Civil War amendments, but its practice contradicted their fundamental values and purposes. Small wonder, then, that some white Southern commentators - the gentleman racist Woodrow Wilson being the classic example - were able to reconcile themselves to the emerging idea that the Court was the defender of the states and the federal structure. 68

While the demands of social change and political expedience shaped the Court's new role, from Reconstruction onwards two particularly acute problems plagued its practice. The first was rooted in the inescapable fact that American federalism was double-sided. The Court, that is, was charged with vindicating national as well as state power, and periodically it turned energetically to upholding the power of the central government and enforcing the national rights the Constitution established. In the early years of the Republic the Court had asserted federal judicial authority over the state courts and sanctioned the doctrine of implied congressional pow-

66. Slaughter-House Cases, 83 U.S. (16 Wall.) 36, 71 (1873) (the "one pervading purpose" of all three amendments was "the freedom of the slave race" and "the protection of the newly-made freemen and citizens,"). See William E. Nelson, The Fourteenth Amendment: From Political Principle to Judicial Doctrine 40-109 (1988); Robert J. Kaczorowski, Congress's Power to Enforce Fourteenth Amendment Rights: Lessons from Federal Remedies the Framers Enacted, 42 HaRv. J. ON Legis. 189 (2005); Robert J. Kaczorowski, Revolutionary Constitutionalism in the Era of the Civil War and Reconstruction, 61 N.Y.U. L. Rev. 863 (1986); Ronald M. Labbe \& Jonathan Lurie, The SlaughterHouse Cases: Regulation, Reconstruction, and the Fourteenth Amendment (2003).

67. Edward A. Purcell, Jr., The Particularly Dubious Case of Hans v. Louisiana: An Essay on Law, Race, History, and "Federal Courts," 81 N.C. L. Rev. 1927, 1975-2039 (2003).

68. On Wilson's racist attitudes, see The Cabinet Diaries of Josephus Daniels, 1913-1921, 32-33 (E. David Cronon, ed., 1963); Arthur S. Link, Woodrow Wilson AND the Progressive Era, 1910-1917, at 64-66 (1954); Arthur S. Link, Wilson: The RoAd to the White House 502 (1947); Henry Wilkinson Bragdon, Woodrow Wilson: The Academic Years 249, 252 (1967). 
ers, ${ }^{69}$ and in the late nineteenth century it began again to expand national powers and to impose muscular federal constitutional limitations on the efforts of the states to regulate economic activities. ${ }^{70}$ Then, in the 1930s, it expanded federal executive power, ${ }^{71}$ extended the powers of Congress drastically, and began laying the groundwork for broad extensions of federal judicial power. ${ }^{72}$ Subsequently, the Warren Court stretched the powers of Congress even further while asserting sweeping federal judicial authority to impose a wide range of new constitutional restrictions on the states. ${ }^{73}$ The idea of the Supreme Court as the defender of the states was thus a concept that offered neither a determinate norm nor a reliable guarantee. ${ }^{74}$

The second problem was that theories about the Court's role in the federal system continued to change with the times. The partial constitutional resolution that resulted from the Civil War that states could not secede from the Union or nullify or authoritatively construe the Constitution - did not stop the flow of history. In the 1890s, for example, Harvard Professor James Bradley Thayer responded to the first steps toward national regulation of business by articulating what he called "The American Doctrine of Constitutional Law." The federal judiciary, Thayer maintained, properly voided executive or legislative acts only when their unconstitution-

69. See e.g., Martin v. Hunter's Lessee, 14 U.S. (1 Wheat.) 304 (1816) (upholding the right of the Supreme Court to review decisions of state courts); McCulloch, 17 U.S. (4 Wheat.) 316 (upholding doctrine of implied congressional power). See also G. EDward White, The Marshall Court and Cultural Change, 1815-1835 (1988).

70. E.g., Edward A. Purcell, Jr., Brandeis and the Progressive Constitution: Erie, the Judicial Power, and the Politics of the Federal Courts in TwentiethCentury America 39-63 (2000).

71. E.g., United States v. Curtiss-Wright Export Corp., 299 U.S. 304 (1936).

72. E.g., Barky Cushman, Rethinking the New Deal Court: The Structure of a Constitutional Revolution pt. IV (1998).

73. E.g., Lucas A. Powe, Jr., The Warren Court and American Politics (2000).

74. "Our theory is structural in that it says that courts have both principled and pragmatic reasons to defer to expansive congressional interpretations of its Commerce Clause authority, while policing rather more vigorously state actions that trespass on their neighbors or on constitutional values... This theory, to the extent that it is borne out in the United States and elsewhere, suggests that courts might be counted on to monitor or police violations of federal understandings quite unevenly." William N. Eskridge, Jr. \& John Ferejohn, The Elastic Commerce Clause: A Political Theory of American Federalism, 47 VAND. L. Rev. 1355, 1398 (1994). 
ality was "so clear that it is not open to rational question."75 This "rule of the clear mistake," however, applied only when the federal courts reviewed "the work of a co-ordinate department," that is, another branch of the federal government. ${ }^{76}$ In contrast, when the national courts reviewed state actions, Thayer urged, they should apply the "true and just construction" of the Constitution - a far more stringent standard that allowed the states not an inch of slack. ${ }^{77}$ Thus, Thayer's theory directed the Court to allow ample flexibility to Congress and the president but to cabin the states rigorously. That Thayer would advance such a double standard was hardly surprising, for he was a Yankee who worshiped John Marshall, spent the Civil War spreading propaganda for the Loyal Publication Society, and cherished above all else the North's triumph in the Civil War, the resulting preservation of the Union, and the full vindication of national authority that followed. ${ }^{78}$

Thayer's theory proved particularly revealing because its subsequent history illustrated the ways in which ideas about the Court's role in the federal system continued to evolve. Many of the great figures of legal Progressivism - including Louis Brandeis, Felix Frankfurter, and Learned Hand - pronounced Thayer's "American doctrine" the summit of constitutional wisdom; but, while ostensibly applying it faithfully, they in fact remolded it adroitly to serve their own new and quite different political purposes. Quietly, they jettisoned Thayer's strict "true and just" standard and extended his deferential "rule of the clear mistake" to federal review of state actions. Unlike Thayer, those legal Progressives were part of a younger generation, emotionally removed from the passions of the Civil War and able to assume easily the Union's triumph and

75. James Bradley Thayer, The Origin and Scope of the American Doctrine of Constitutional Law, 7 Harv. L. Rev. 129, 144 (1893).

76. Id. at 150. See Edward A. Purcell, Jr., Learned Hand: The Jurisprudential Trajectory of an Old Progressive, 43 Buff. L. Rev. 873, 884-96 (1995).

77. See Thayer, supra note 75, at 144 (1893).

78. Purcell, supra note 76, at 886-90. Not surprisingly, Thayer's attitude was shared by another Yankee whose constitutional jurisprudence was also forged by the Civil War, Justice Oliver Wendell Holmes, Jr. "I do not think the United States would come to an end if we lost our power to declare an Act of Congress void," Holmes declared. "I do think the Union would be imperiled if we count not make that declaration as to the laws of the several States." Oliver Wendell Holmes, Jr., Law and the Court, in Collected Legal Papers 291, 295-96 (1920). 
preservation. They saw not nullification and secession but industrialization and social reform as their generation's overriding challenge. Inspired by faith in science, progress, and popular government, they distrusted the courts as biased and ill-informed, and they embraced the legislature as the popular instrument of science, expertise, and rational progress. ${ }^{79}$ Consequently, they sought to prevent the courts from voiding legislative reforms, and in Thayer's "rule of the clear mistake" they found a highly useful device - once they had suitably redesigned it — to free the legislatures of the states as well as the nation from close judicial oversight. ${ }^{80}$

Thayer's original theory and its Progressive reformulation implied strikingly different roles for the federal judiciary vis a vis the states. The two versions demonstrated not only that theories of judicial review evolved over time but also that their inspiration lay in changing social and political purposes. They revealed that theories about the Court's role were contingent ideas rooted not in unchanging principles of either federalism or judicial review but in the politics of the nation's ongoing enterprise of constitutional selfgovernment.

As slavery, the Civil War, industrialization, and Progressivism generated a sequence of shifting ideas about the Court's role in the federal system, the new context that evolved in the mid twentieth century similarly generated its own new and distinctive theories. The Great Depression, the New Deal, World War II, and the stunning postwar economic boom expanded the size of the federal government and cast on it primary responsibility for overseeing the economy and sustaining the nation's prosperity. ${ }^{81}$ Combined with the threat of "totalitarianism," the dangers of the cold war, and the emerging movement for black civil rights, however, those developments also brought unnerving new anxieties. If bigger government

79. Purcell, supra note 76, at 889-91; PurCELl, supra note 70 , at ch. 1 .

80. Purcell, supra note 76, at 889-91.

81. See, e.g., William J. Novak, The Legal Origins of the Modern American State, in Looking Back At Law's Century 249, 249 (Austin Sarat et al. eds., 2002); see generally Alan Dawley, Struggles for Justice: Social Responsibility and the Liberal State (1991); Alan Brinkley, The End of Reform: New Deal Liberalism in Recession and War (1995); John Patrick Diggins, The Proud Decades: America in War and Peace, 1941-1960 (1988); The Rise and Fall of the New Deal Order, 1930-1980 (Steve Fraser \& Gary Gerstle eds., 1989). 
was necessary, but at the same time if government at all levels could threaten individual liberties, then some institutional bulwark was essential to preserve democracy and protect the rights of individuals. Like the defenders of the states after the Civil War, but unlike their Progressive forebears, post-World War II liberals transferred their hopes to the federal judiciary, and they did so with the stereotypical ardor of converts. ${ }^{82}$

Their basic intuition was simple, yet sweeping. If all governments could endanger individual rights and liberties, then constitutional rights needed special protection, and a judiciary — especially one with life-tenured judges - seemed the ideal institution to undertake the task. Liberals began to argue that the judiciary should enforce the Bill of Rights vigorously and, moreover, apply its guarantees not only to the national government but to the states as well. From hesitant beginnings in the 1920s and 1930s, the Court began increasingly to fulfill that prescription by expanding the reach of the Equal Protection and Due Process Clauses and by enforcing the guarantees of the first eight Amendments against the states as well as the federal government. ${ }^{83}$

As events unfolded, new theories surfaced to explain and legitimize the Court's shift. In the 1920s Brandeis insisted that the judiciary should guard the right of free speech because its role as an instrument of democracy made it "a fundamental principle of the American government." ${ }^{4}$ A decade later Justice Benjamin N. Cardozo suggested that the protections in the Bill of Rights were properly binding on the states when they were essential to the nation's

82. See, e.g., Mary L. Dudziak, Cold War Civil Rights: Race and the Image of American Democracy (2000); Mark A. Graber, Transforming Free Speech: The Ambiguous Legacy of Civil Libertarianism (1991); Morton J. Horwitz, The Transformation of American Law, 1870-1960: The Crisis of Legal Orthodoxy, ch. 9 (1992); Powe, supra note 73; Barry Friedman, The Birth of an Academic Obsession: The History of the Countermajoritarian Difficulty, Part Five, 112 Yale L.J. 153 (2002); Reuel E. Schiller, Enlarging the Administrative Polity: Administrative Law and the Changing Definition of Pluralism, 1945-1970, 53 Vand. L. Rev.1389 (2000); Reuel E. Schiller, Free Speech and Expertise: Administrative Censorship and the Birth of the Modern First Amendment, 86 VA. L. REv. 1 (2000).

83. See Paul L. Murphy, The Constitution in Crisis Times 1918-1969 (1972); James F. Simon, The Antagonists: Hugo Black, Felix Frankfurter and Civil Liberties in Modern America (1989); Roger K. Newman, Hugo Black: A Biography (1994).

84. Whitney v. California, 274 U. S. 357, 372, 375 (1927) (Brandeis, J., concurring). 
"scheme of ordered liberty," 85 while Justice Harlan F. Stone sketched a more general theory that identified the courts as guarantors of both individual rights and open democratic processes. ${ }^{86}$ In the years after World War II those germinal ideas increasingly bore fruit. Henry Hart began his extended effort to reconceive the role of the national judiciary and to enhance its authority in the federal system; ${ }^{87}$ Alexander Bickel hailed the Court as the "pronouncer and guardian" of the nation's "enduring values" 88 ; and judges increasingly acted on the idea that they had special obligations to safeguard a widening range of fundamental individual liberties.

Those developments flowed from the dominant liberal values that flourished in the post-World War II decades. ${ }^{89}$ Like their Progressive ancestors, mid-twentieth-century liberals designed their theories to preserve wide areas of democratic lawmaking for the legislative branch, especially its power to regulate the economy. Unlike those Progressives, however, they also designed their theories to carve out a special and active role for the courts in protecting individual non-economic rights and liberties. More particularly, in terms of the federal system, they designed their theories to discount the role of the courts as protectors of the states and to enhance their contrary role as vindicators of national law and national rights. ${ }^{90}$

85. Palko v. Connecticut, 302 U.S. 319, 325 (1937). See Andrew Kaufman, CarDOzo 552-54 (1998).

86. See Carolene Products Co. v. United States, 304 U.S. 144 (1938). As early as 1940 Justice Hugo Black, an ardent New Dealer and President Franklin Roosevelt's first appointee to the high bench, was poised to declare sweepingly that the courts "stand against any winds that blow as havens of refuge for those who might otherwise suffer because they are helpless, weak, outnumbered, or because they are non-conforming victims of prejudice and public excitement." Chambers v. Florida, 309 U.S. 227, 241 (1940).

87. Purcell, supra note 70, at 234-46.

88. Alexander M. Bickel, The Least Dangerous Branch: The Supreme Court At the Bar of Politics 188, 24, 25 (1962). See Friedman, supra note 82.

89. The theories reflected, among other things, the values of the New Deal coalition and its jurisprudential triumph. Edward A. Purcell, Jr., Brandeis, Erie, and the New Deal "Constitutional Revolution," 26 J. Sup. Cт. Hist. 257, 263-76 (2001).

90. The Court began, for example, to construe the Establishment Clause to limit states and localities in various, if sometimes inconsistent, ways. See McCollum v. Bd. of Educ., 333 U.S. 203 (1948) (invalidating a state released time program for religious instruction); Noah Feldman, From Liberty to Equality: The Transformation of the Establishment Clause, 90 Cal. L. Rev. 673, 682-93 (2002). See generally Howard Gillman, Preferred 
In 1954 two events nourished the full flowering of the new liberal conviction about the Court's role in the federal system. First, on the level of theory, Herbert Wechsler, an ex-New Dealer who taught at the Columbia Law School, published an essay entitled "The Political Safeguards of Federalism."91 Wechsler argued that the Constitution protected the states by making them constituent elements of the federal government, by granting them equal representation in the Senate, authority to select the president through the Electoral College, and the right to control voting and districting for the House. ${ }^{92}$ Because those and other such "political safeguards" ensured that the federal government would heed the states and respect their interests, he reasoned, the Supreme Court need not do so. Indeed, recognition of the "political safeguards" showed that the Court's distinctive constitutional task was not to protect federalism at all but, rather, to protect those constitutional values that the "political safeguards" failed to guarantee: first, the supremacy of federal law and, second, the federal constitutional rights of individuals and minorities. ${ }^{93}$

Freedoms: The Progressive Expansion of State Power and the Rise of Modern Civil Liberties Jurisprudence, 47 Pol. REs. Q. 623 (1994).

91. Herbert Wechsler, The Political Safeguards of Federalism: The Role of the States in the Composition and Selection of the National Government," 54 Colum. L. REv. 543 (1954).

92. Wechsler's theory, though "structural" in form, was also based on ideas of "original intent." His analysis drew on and tracked many of the arguments that the Federalists of 1787-89 had offered in defense of the new Constitution. See, e.g., supra text accompanying notes 59-60.

93. The belief that the Court's role was to curb the states, not the national government, reflected the thinking of many of the founders and became widely shared among post-World War II liberals. "If judicial review in a federal system were to be appraised solely on the basis of control over national legislation or cooperative measures, the cost in terms of doubt and occasional delay would outweigh the value," one distinguished constitutional scholar declared. "But judicial review is intended preeminently as a restraint on state action," and it was to those decisions "that we must turn for a proper evaluation of the role of the Court . . .." Paul A. Freund, Umpiring the Federal System, in Federalism: Mature and Emergent 159, 163 (Arthur W. MacMahon ed., 1955). Federal judicial review of presidential and congressional actions "may be thought to pose a problem," another equally prominent scholar announced, but there was "no problem about the fundamental legitimacy of [federal] judicial review of the actions of the states for federal constitutionality." Charles L. Black, Jr., Structure and Relationship in Constitutional Law 73 (1969). 
Second, on the level of action, the Court handed down its monumental decision in Brown v. Board of Education. ${ }^{94}$ The decision invalidated Plessy v. Ferguson ${ }^{95}$ one of the landmarks of the postReconstruction constitutional settlement, by ruling racial segregation in public schools unconstitutional under the Equal Protection Clause. ${ }^{96}$ With respect to the federal system, the decision drove a dagger through the political heart of the post-Civil War idea of the Court as protector of the states, and it inspired a galvanizing new image of the federal judiciary as the protector of national rights and national liberties. During the next fifteen years, under the leadership of Chief Justice Earl Warren, the Court issued a series of bold centralizing decisions in a variety of areas and quickly came to stand as a symbol of liberalism, nationalism, and the judicial protection of the weak and disadvantaged. ${ }^{97}$

While liberal and activist ideas about the Court's role spread rapidly during the $1960 \mathrm{~s}$ and into the $1970 \mathrm{~s},{ }^{98}$ national politics and consequently the Court's membership - began to change after the Republican presidential victory of 1968 . Under a variety of internal and external pressures, the post-war liberal consensus began to fragment, and critics increasingly advanced a battery of objections to the Court's expansive, liberal, and national orientation. Bickel abandoned his earlier views and began to criticize the Warren Court sharply, maintaining that the judiciary should not create new constitutional rights but should, instead, defer to the democratically-elected branches of both nation and states. ${ }^{99}$ Raoul Berger scoured the historical record for evidence that the "original

94. 347 U.S. 483 (1954). See generally James T. Patterson, Brown v. Board of Education: A Civil Rights Milestone and its Troubled Legacy (2001) (discussing the decision and its legacy).

95. 163 U.S. 537 (1896) (upholding legalized racial segregation on railroads).

96. Brown, 347 U.S. 483.

97. For more on the Warren Court, see Morton J. Horwitz, The Warren Court and the Pursuit of Justice (1998); Powe supra note 73; Bernard Schwartz, The Warren Court: A Retrospective (1996).

98. Liberal ideas subsequently received two of their most elaborate theoretical formulations in Jesse H. Choper, Judicial Review and the National Political Process: A Functional Reconsideration of the Role of the Supreme Court (1980), and John Hart Ely, Democracy and Distrust: A Theory of Judicial Review (1980).

99. Bickel, for example, moved toward this position in the late 1960s. See generally Alexander M. Bickel, The Supreme Court and the Idea of Progress (1970); Alexander M. Bickel, The Morality of Consent (1975); see also Edward A. Purcell, Jr., Alexan- 
intent" of the founders was to establish the Court as the institution charged with enforcing clear constitutional limits on the national government and enforcing a substantive Tenth Amendment. ${ }^{100}$ Lewis Kaden probed the weaknesses of the "political safeguards" theory itself, showing how changes over time had eroded the institutional ability of the states to protect themselves through the constitutive roles they played in the national government. ${ }^{101}$ Historical changes, Kaden suggested, might require the Court to adopt a new and different role in protecting federalism. ${ }^{102}$

Somewhat out of the mainstream, conservative scholars such as Richard Epstein and Philip Kurland advanced more striking positions. Epstein argued that "judicial activism" was fine but that it was being used on behalf of the wrong substantive values. It should be used not to enforce liberal policies but to promote conservative and free market principles across the board, including the protection of the states against extensions of federal power. ${ }^{103}$ Kurland, a devout advocate of decentralization, simply despaired. Reviving the AntiFederalist forebodings of Brutus, he insisted that the Court was "an integral part of the central government" and that it lacked the power to block the process of centralization. The Court's efforts, he lamented, could only bring "a constant attrition of state power."104

As Republican appointments slowly transformed the Court, its orientation began haltingly to shift, exhibiting a fading concern for civil rights and a growing sympathy for states' rights. As early as

der M. Bickel and the Post-Realist Constitution, 11 HARv. C.R.-C.L. L. REv. 521, 543-63 (1976).

100. See, e.g., Raoul Berger, Federalism: The Founder's Design 188 (1987) (stating that constitutional principles "may not be divorced from the Founders' own explanations of what they intended to accomplish").

101. See Louis Kaden, Politics, Money, and State Sovereignty: The Judicial Role, 79 Colum. L. Rev. 847 (1979); Stephen G. Calabresi, A Government of Limited and Enumerated Powers; In Defense of United States v. Lopez, 94 Mich. L. Rev. 752 (1995); John C. Yoo, The Judicial Safeguards of Federalism, 70 S. CAL. L. REv. 1311 (1997).

102. Kaden, supra note 101.

103. See Richard A. Epstein, Takings: Private Property and the Power of Eminent Domain (1985); Richard A. Epstein, Forbidden Grounds: The Case "Against Employment Discrimination Laws (1992); Richard A. Epstein, Bargaining With the STATE (1993).

104. Philip B. Kurland, Politics, the Constitution, and the Warren Court 57 (1970). 
1976 five justices invoked the Tenth Amendment to limit congressional power, ${ }^{105}$ seemingly reversing some forty years of post-New Deal case law that ignored the amendment. ${ }^{106}$ Less than a decade later, however, five justices invoked the "political safeguards" idea to again reverse course, though their effort drew the scathing fire of four conservatives who vehemently rejected the liberal theory. ${ }^{107}$ The "political safeguards" idea, one declared, was "an outright rejection" of "the intention of the Framers of the Constitution." 108 Finally, by the early 1990s, Republican appointments had created a solid five-Justice conservative bloc. Under Chief Justice William Rehnquist, the new Court began to move consistently and purposefully to invoke the values and principles of federalism, enhance the independence of the states, and limit the powers of Congress. ${ }^{109}$ In the process it struck down a dozen federal statutes, construed federal civil rights laws narrowly, and pronounced itself forthrightly the constitutional protector of the states and the federal system. ${ }^{110}$

Understandably, the Rehnquist Court's reorientation of the national judiciary led liberals to rethink their theories about the Court and its proper role. While some attempted to strengthen the "political safeguards" argument to challenge the Court's proclaimed role as the protector of federalism, ${ }^{111}$ others turned to broader theories

105. Nat'l League of Cities v. Usury, 426 U.S. 833, 852 (1976) (holding that the Tenth Amendment prohibited Congress from intruding into the "traditional government functions" of the states).

106. See e.g., United States v. Darby, 312 U.S. 100 (1941) (affirming extensive congressional power and denying that the Tenth Amendment constituted an independent and substantive limit on national powers).

107. Garcia v. San Antonio Metro. Transit Auth., 469 U.S. 528 (1985) (overruling National League of Cities, 426 U.S. 833).

108. Id. at 577 (Powell, J., dissenting).

109. E.g., Gregory v Ashcroft, 501 U.S. 452 (1991); New York v. United States, 505 U.S. 144 (1992) (enforcing a constitutional limit on the federal government's power to compel states to take regulatory actions and inaugurating a series of subsequent decisions limiting federal power and providing immunities to the states and their officials); Seminole Tribe v. Florida, 517 U.S. 44 (1996); Printz v. United States, 521 U.S. 898 (1997); Fla. Prepaid Postsecondary Educ. Expense Bd. v. Coll. Sav. Bank, 527 U.S. 627 (1999); Bd. of Trustees v. Garrett, 531 U.S. 356, 365 (2001).

110. E.g., United States v. Lopez, 514 U.S. 549 (1995); City of Boerne v. Flores, 512 U.S. 507 (1997); United States v. Morrison, 529 U.S. 598 (2000). See Seth P. Waxman, Defending Congress, 79 N.C. L. REv. 1073 (2001).

111. E.g., Larry Kramer, Putting the Politics Back into the Political Safeguards of Federalism, 100 Colum. L. Rev. 215 (2000). 
that limited the constitutional role of the national courts on more fundamental grounds. Mining the past, liberal scholars began to invoke ideas of "originalism," "departmentalism," and "popular sovereignty" to maintain that the conservative federal judiciary was acting beyond its assigned role and improperly interfering with the judgments of Congress and the results of the nation's democratic processes. ${ }^{112}$ "The Constitution does not mean only what the judges say it means," Cass Sunstein declared in 1993, "[o]n the contrary, the Constitution has often served as a catalyst for broad public deliberation about its general terms and aspirations." 113 The meaning that non-judicial government officials and "citizens in general" gave the Constitution over the years, he insisted, "has been more important than its meaning within the narrow confines of the Supreme Court building." 114 Richard Parker put the point bluntly. "[T]he authority of constitutional argument by judges is defeasible — indeed, it ought to be challenged periodically." 115 Ultimately, judicial decisions "must appeal to ordinary people," for the people retained the right to make the truly final decision on disputed constitutional questions. ${ }^{116}$

To that new liberal tack the majority justices on the Rehnquist Court countered with unqualified assertions of federal judicial supremacy. "The power to interpret the Constitution in a case or controversy," it insisted, "remains in the judiciary."117 Notwithstanding the broad constitutional powers of Congress, "it is the responsibility of this Court, not Congress, to define the substance of constitutional guarantees."118 The Rehnquist Court's decisions

112. Kramer, supra note 7; Richard D. Parker, "Here, the People Rule": A Constitutional Populist Manifesto 71-77, 108-15 (1994); Mark Tushnet, Taking the Constitution Away from the Courts (1999); Robert C. Post \& Reva B. Siegel, Legislative Constitutionalism and Section Five Power: Policentric Interpretation of the Family and Medical Leave Act, 112 YALE L.J. 1943 (2003). For a survey of the varieties of such theories see James E. Fleming, The Constitution Outside the Courts, 86 Cornell L. REv. 215 (2000).

113. Cass R. Sunstein, The Partial Constitution, vi (1993).

114. Id.

115. PARKer, supra note 112, at 111.

116. Id.

117. City of Boerne, 521 U.S. at 524.

118. Garrett, 531 U.S. at 365 . In 1958, during the darkest days of the post-Brown civil rights movement, it had been the liberal Warren Court that defended itself against the attacks of Southern segregationists by forthrightly announcing the principle of judicial supremacy. The "basic principle" of American constitutional law, it proclaimed, was 
trumpeted loudly its conviction that the Court held both the ultimate duty and the final authority to enforce the principles of federalism as a constitutional mandate. ${ }^{119}$ Its sweeping assertions of judicial authority echoed nothing so much as the Warren Court's similar assertions more than three decades earlier when it was forced to answer Brown's critics and establish its own authority to enforce racial desegregation of the public schools. ${ }^{120}$

Thus, at the beginning of the twenty-first century the question of the Court's proper role in the federal system remained sharply and broadly contested. Spurred by sweeping political, cultural, ideological, and institutional changes, judges and commentators cleverly reworked the available fund of ideas to serve new purposes. Despite massive amounts of historical research and the elaboration of ever more sophisticated "theories" of constitutional interpretation, however, they seemed unable to convince those with differing ideological commitments that they had identified either the "true" nature of the federal system or the Court's "true" role in it. On one level, of course, the reason for their failure was simple. Neither the Constitution nor any other authoritative source unequivocally defined such a system or such a role.

\section{Changing Ideas About the "Values" of Federalism}

The vigorous debate about the Court's proper role in the federal system reflected profound changes in American politics. The impact of those changes was nowhere more obvious than in the rapidly multiplying discussions about the "values of federalism" that began to proliferate in the late twentieth century. ${ }^{121}$ The discussions

"that the federal judiciary is supreme in the exposition of the law of the constitution" and that its rulings constituted "the supreme law of the land." Cooper v. Aaron, 358 U.S. 1, 18 (1958). The nature of the "supremacy" the Court announced has been variously interpreted. See, e.g., Laurence Tribe, American Constitutional Law 255-267 (3d ed., 2000).

119. Lopez, 514 U.S. 549; Printz, 521 U.S. 898; Morrison, 529 U.S. 598. Many scholars supported the Court's position. E.g., John O. McGinnis \& Ilya Somin, Federalism vs. States' Rights: A Defense of Judicial Review in a Federal System, 99 Nw. U. L. REv. 89 (2004).

120. Cooper, 358 U.S. 1.

121. The literature on federalism exploded in the 1980s, and many of the discussions focused on its reputed "values," which were usually described as including protecting liberty, encouraging diversity and innovation, ensuring political accountability, promoting democratic participation, and protecting local values and interests. See, e.g., 
were curious and revealing. Often they were almost tautologically abstract, treating the "values of federalism" as necessary logical inferences from unspecified prescriptive theories rather than as historical consequences that were - or were not - actually connected to the operations of the existing federal system. Further, they were frequently based on dubious assumptions. Often, for example, they implied that such "values of federalism" as "political accountability" and "popular participation" were served better at the state than at the national level on the doubtful premise that state governments were small-scale institutions interacting face-toface with their citizens rather than impersonal bureaucracies governing millions upon millions of people from great social and political, if not always geographical, distances. ${ }^{122}$

Most striking, however, discussions about the "values of federalism" revealed an acute, if often implicit, awareness that the federal system had changed drastically over the years and that in many areas the role of the states had grown uncertain, unsatisfying, or perhaps even unnecessary. Thus, the implicit premise that drove such discussions seemed to be an anxious sense that many "traditional" lines ostensibly separating national and state power were no longer sound, easily detectable, or even operationally plausible. Some kind of functional analysis seemed necessary to justify the existence of the states as independent governing units, to assure Americans that those state governments actually produced public benefits, and to identify useful and intelligible lines that could be drawn between federal and state authority. ${ }^{123}$ The intense concern with the "values of federalism," in other words, evidenced the ex-

Richard B. Stewart, Federalism and Rights, 19 GA. L. REv. 917 (1985); Erwin Chemerinsky, The Values of Federalism, 47 FL. L. REv. 499 (1995); Larry Kramer, Understanding Federalism, 47 VAND. L. Rev. 1485 (1994).

122. William H. Riker, Federalism: Origin, Operation, Significance, 139-45 (1964); Richard Briffault, "What About the 'Ism'?" Normative and Formal Concerns in Contemporary Federalism, 47 VAND. L. Rev. 1303 (1994); Edward L. Rubin, The Fundamentality and Irrelevance of Federalism, 13 GA. ST. U. L. Rev. 1009 (1997); Edward L. Rubin \& Malcolm Feeley, Federalism: Some Notes on a National Neurosis, 41 U.C.L.A. L. REv. 903 (1994).

123. See Stewart, supra note 121. To reiterate a key point, the argument of this essay is not that the states and the federal system have no value but that their value is historically contingent and that their contributions must be examined in detail by time, place, and issue. C.f., Vicki C. Jackson, Federalism and the Uses and Limits of Law: Printz and Principle?, 111 Harv. L. Rev. 2180 (1998). 
tent to which massive changes during the preceding two centuries had created a deep-seeded uncertainty about the nature, meaning, and significance of American federalism itself.

The substance of those discussions, moreover, highlighted the ambiguous and fluid nature of the "values" proposed to be "of federalism." Consider, for example, what was probably the most fundamental and widely accepted of those values, "preserving liberty." As conservative Justice Lewis F. Powell, Jr. voiced the standard claim, the constitutional power of the states was "designed to protect our fundamental liberties" by creating checks on the national government. ${ }^{124}$ That "value of federalism," however, provided little guidance as theory and encouraged little confidence as history.

As for theory, the value of "protecting liberty" ignored the double-sided nature of American federalism, the fact that the national government was also designed to protect liberty from the abuses of the states. ${ }^{125}$ The Federalists of 1787-89 "were much more troubled over the irresponsibility and small-mindedness of the state legislatures in the years immediately following the Revolution than they were over the deficiencies of the Articles of Confederation," Stanley Elkins and Eric McKitrick explained. "What most offended them were such short-sighted actions as paper money laws, debtor relief laws, local tariffs, tax postponements, and a tendency to beat down court reforms and similar undertakings intended for the larger public benefit." ${ }^{26}$ Further, the value ignored the more fundamental truth that "liberty" was seldom, if ever, protected in the abstract or in general. Rather, in practice, liberty required protection only from live and specific threats, and in such cases "protecting liberty" invariably meant choosing to protect some liberties to some extent in some contexts and against some restrictions. Thus, as an abstract and theoretical matter, the value of "protecting liberty" was as incontestible as it was non-directive.

124. Garcia, 469 U.S. at 557, 572 (Powell, J., dissenting). The "liberty" argument is developed in John Choon Yoo, Federalism and Judicial Review, in The Tenth Amendment and State Sovereignty: Constitutional History and Contemporary Issues 131, 178 79 (2002).

125. See, e.g., James Madison, Vices of the Political System of the United States, in 9 THE Papers of James Madison supra note 36, 345-58; Jack N. Rakove, Constitutional Problematics, circa 1787, in Constitutional Culture and Democratic Rule 41, 57-60 (John Ferejohn, Jack N. Rakove, \& Jonathan Riley eds., 2001).

126. See Elkins \& McKitrick, supra note 22, at 702. 
As for history, the states had repeatedly proven themselves highly unreliable protectors of liberty. Neither state nor local governments had been relatively more successful at the task of protecting liberty than the national government, and after the Civil War and the passage of the Fourteenth Amendment the federal government emerged - gradually and painfully — as the primary governmental force protecting and expanding the liberties of American citizens. ${ }^{127}$ The nation's long and tragic history of racial oppression, moreover, unequivocally identified the states - especially some fifteen or more southern and border states - as the nation's most flagrantly egregious post-Civil War oppressors of "fundamental liberties."128

Equally important, when the federal government did fail to protect civil liberties and itself became an oppressor — as it did, for example, in the years around World War I and again during the McCarthy era - the states not only failed to act as checks on the national government but indulged in their own abuses which often exceeded those of the national government. ${ }^{129}$ During World War

127. "Even the most casual survey of the United States Reports reveals that in every area of constitutionally designated individual liberties - whether it be speech, race, religion, the rights of the accused, or any other - the record of the state and local governments has been far inferior to that of the nation." CHOPER, supra note 98, at 25253. "The model of federalism derived from history cannot, therefore, give much support to those who equate decentralization with freedom." Harry N. Scheiber, Federalism and Legal Process: Historical and Contemporary Analysis of the American System, 14 L. \& Soc'Y REv. 663, 706 (1980).

128. Since the termination of the Civil War, Americans have concluded that they can no longer trust their liberties to federalism. Sovereignty must be concentrated in the hands of the national government. Quite apart from the dangers of civil war, the powers of state and local governments have been used too often by a tyrannical majority to trample the rights of religious, racial, and political minorities. The courts now seem a more reliable institutional shelter for the nation's liberties.

Paul E. Peterson, The Price of Federalism 9 (1995).

129. "There seemed to be a race among the various states [during the "red scare" of 1919-20] for the most drastic legislation, and vested interests, their influence enhanced by the makeup of the state legislatures, pushed through the bills . . . . On the whole, one may perhaps say that the federal system may have speeded up inroads into the civil liberties rather than have protected them." Franz L. Neumann, Federalism and Freedom: A Critique, in Federalism: Mature and Emergent, supra note 93, at 44, 48. Accord Ellen W. Schrecker, No Ivory Tower: McCarthyism \& THe Universities 93-125 (1986). Most scholarship has focused on the actions of the federal government. On the first "Red Scare," see William Preston, Jr., Aliens and Dissenters: Federal Sup- 
I at least eleven states and dozens of cities passed sedition laws prohibiting disloyal speech, while most states established special "councils of defense" that pressured citizens to buy war bonds and used threats or punitive sanctions against those who refused. ${ }^{130}$ Further, in the succeeding "Red Scare" numerous states passed criminal syndicalism statutes, and thirty-two adopted laws that prohibited anyone from flying the Red flag. By the end of 1920s the states had arrested more than 1,400 people under those statutes, convicting more than 300 and imposing sentences that ranged up to twenty years in prison. ${ }^{131}$ Similarly, during the McCarthy era, state and local governments again simply followed along. Fortyfour states criminalized speech that advocated the overthrow of government, while forty-two - plus well over two thousand local and municipal governments - required public employees to sign loyalty oaths. Every state in the Union banned Communists and their alleged sympathizers from admission to the bar, while thirty-five prohibited Communist Party candidates from running for office. For mere membership in the party, moreover, Texas imposed a twenty-year prison sentence, while Michigan opted for a life term. Tennessee, however, took the prize. The Volunteer State determined that membership warranted death. ${ }^{132}$

Most recently, the United States government enacted the USA PATRIOT Act ${ }^{133}$ and committed egregious violations of constitutional rights by arresting and imprisoning thousands of individuals, including American citizens, and holding them for months or years without legal counsel or access to a judicial forum. ${ }^{134}$ Notwithstanding the proclaimed "values of federalism" and the hypothe-

PRESSion OF Radicals, 1903-1933 (1963). On McCarthyism, see Stanley I. Kutler, The American Inquisition: Justice and Injustice in the Cold War (1982).

130. STONe, supra note 27 , at 181-82.

131. Id. at 224 .

132. Id. at $340-41,422-23$.

133. Uniting and Strengthening America by Providing Appropriate Tools Required to Intercept and Obstruct Terrorism (USA PATRIOT) Act, Pub. L. No. 107-56, 115 Stat. 272 (Oct. 26, 2001).

134. Stephen J. Schulhofer, At War With Liberty, the American Prospect (2003), available at http://www.prospect.org/print/V14/3/schulhofer-s.html; STEPHEN J. Schulhofer, The Enemy Within: Intelligence Gathering, Law Enforcement, and Civil Liberties in the Wake of September 11 (2003); Eric Lichtblau, Two Groups Charge Abuse of Witness Law, N.Y. Times, June 27, 2005, at A10. 
sized role of the states in protecting "liberty," however, the states failed to "check" those actions of the national government. They could not intervene in any direct way to counter or obstruct the policy of the national government, and the protest resolutions that some states and literally hundreds of local governments adopted seemed unavailing and, in the short run at least, futile. ${ }^{135}$ Thus, while "protecting liberty" was a central and unquestionable constitutional value, its relationship to the federal structure was, at best, dubious and unproven.

Another proffered "value of federalism" was the ability of states to benefit the nation by serving as independent "laboratories" for social "experiments." The idea, as Justice Oliver Wendell Holmes, Jr. phrased it in 1921, was that states were "insulated chambers" that could conduct "social experiments that an important part of the community desires" and that, if successful, the experiments would redound to the benefit of the nation as a whole. ${ }^{136}$ This concept became popular, and the majority justices on the Rehnquist Court embraced it fervently as a principal justification for their "pro-feder-

135. Proponents of civil liberties attempted to use state and local governments to rally opposition to national policy. As of September 2005, according to a count made by the American Civil Liberties Union, resolutions criticizing all or parts of the Patriot Act were passed in seven states (Colorado, Montana, Idaho, Maine, Vermont, Alaska, and Hawaii) and 389 local communities. See American Civil Liberties Union (ACLU), http://www.aclu.org?SafeandFree.cfm?ID=11294\&c=207 (last visited Sept. 16, 2005). See Ernest A. Young, Welcome to the Dark Side: Liberals Rediscover Federalism in the Wake of the War on Terror, 69 BRook. L. Rev. 1277 (2004).

136. Truax v. Corrigan, 257 U.S. 312, 342, 344 (1921) (Holmes, J., dissenting). Akhil Reed Amar noted that

the laboratory perspective distorts even as it illuminates. If the nationalist slights the role of the states in 'checking' the nation, the laboratory perspective simply reverses the skee by ignoring the role of the nation in policing the states. Indeed, the laboratory perspective fails to offer any affirmative account whatsoever of national legislation.

Akhil Reed Amar, Five Views of Federalism: "Converse-1983 in Context," 47 Vand. L. Rev. 1229, 1235 (1994). 
alism" agenda. ${ }^{137}$ The idea was, however, both non-directive and non-authoritative. ${ }^{138}$

First, like the value of "protecting liberty," the idea of the states as "laboratories" conducting "experiments" was double-sided and offered no help in identifying specific lines between state and national authority, between "experiments" that the Constitution allowed and those that it barred. Indeed, the idea invariably provoked an automatic and, in the abstract, unanswerable response. As Chief Justice William Howard Taft phrased it in Truax v. Corrigan, the "Constitution was intended - its very purpose was to prevent experimentation with the fundamental rights of the individual."139 Thus, the laboratory metaphor merely rerouted normative evaluation back to the original ambivalence of American federalism.

Second, the idea of the states as laboratories was not a premise of the Constitution. Although the founders were well aware of both the dangers of state rivalries and the value of state experience in constitution making, ${ }^{140}$ they did not consider state power as part of any beneficent scheme to encourage social experimentation. To the contrary, they deplored many of the legislative expedients the states adopted after Independence and sought precisely to limit their ability to conduct such "experiments." Most assiduously, the founders strove to bar the states from enacting measures that would disrupt the social and economic order, such as debtor relief acts, local tariffs, and paper money laws. ${ }^{141}$ The "loss which America has

137. See Lopez, 514 U.S. at 581 (Kennedy, J., concurring); West Lynn Creamery, Inc. v. Healy, 512 U.S. 186, 212-17 (1994) (Rehnquist, C.J., dissenting); Gregory v. Ashcroft, 501 U.S. 452, 458 (1991); Cruzan v. Mo. Dep't of Health, 497 U.S. 261, 292 (1990) (O'Connor, J., concurring); Fed. Energy Regulatory Comm'n v. Mississippi, 456 U.S. 742, 787-88 (1982) (O'Connor, J., concurring in the judgment and dissenting in part). Another of the Court's late twentieth-century conservatives, Justice Lewis Powell, invoked the laboratory metaphor in Garcia, 469 U.S. at 568 n.13 (Powell, J., dissenting).

138. The point is not that states cannot and do not attempt policy "experiments," but rather that the "laboratory" idea does not resolve the fundamental problem of federalism, drawing the line between national and state power.

139. Truax, 257 U.S. at 338.

140. See, e.g., Riker, supra note 122, at 31; Martin Diamond, What the Framers Meant by Federalism, in A Nation of States: Essays on the American Federal System 25, 34 (Robert A. Goldwin ed., 2d ed. 1974).

141. See, e.g., James Madison, Vices of the Political System of the United States, in 9 THE Papers of James Madison supra note 36, at 345-58; Gordon S. Wood, Interests and Disin- 
sustained since the peace, from the pestilent effects of paper money," Madison protested, caused catastrophic damage and "constitutes an enormous debt against the States chargeable with this unadvised measure ..."142 Such folly could be "expiated" only by the "voluntary sacrifice" of state power. ${ }^{143}$ If "the sovereignty of the States cannot be reconciled to the happiness of the people," Madison declared, only one choice was possible: "Let the former be sacrificed to the latter." 144 Reviewing the debates at the Constitutional Convention, Jack Rakove concluded that "[n] othing in these arguments suggested that [the drafters] regarded the states as laboratories of liberty or nurseries of republican citizenship." ${ }^{145}$

Although nineteenth-century Americans came to recognize that the states sometimes competed by adopting novel social policies, ${ }^{146}$ only in the twentieth century did they generalize the idea,

terestedness in the Making of the Constitution, in Beyond Confederation: Origins of the Constitution and American National Identify 69-109 (Richard Beeman, Stephen Botein, \& Edward C. Carter II eds., 1987); Jack N. Rakove, Constitutional Problematics, circa 1787, in Constitutional Culture and Democratic Rule 41, 57-60 (John Ferejohn, Jack N. Rakove, \& Jonathan Riley eds., 2001).

142. The Federalist No. 44, supra note 12, at 290 (James Madison).

143. Id. Even Elbridge Gerry, who warned the Philadelphia convention that national power could "enslave the States" and subsequently opposed ratification, announced that he "had no objection to authorize a [federal] negative to paper money and similar measures." 1 ReCORds OF THE Federal Convention of 1787, at 165 (alteration in original) (Max Farrand ed., 1960) available at http://memory.loc.gov/cgi-bin/ query/r?ammem/hlaw:@field(DOCID+@lit(fr0012)) (follow "Page image" hyperlink).

144. The Federalist No. 45, supra note 12, at 299 (James Madison). Defending the checking power of the Senate, the authors emphasized the same point: "[T]he facility and excess of lawmaking seem to be the diseases to which our governments are most liable ...." The Federalist No. 62, supra note 12, at 402 (Alexander Hamilton or James Madison).

145. Jack N. Rakove, Original Meanings: Politics and Ideas in the Making of the Constitution 170 (1996). Accord Riker, supra note 122, at 14-15.

146. See, e.g., Anderson v. Dunn, 19 U.S. (6 Wheat.) 204, 226 (1821) (stating that government in the United States became "the science of experiment"), cited in HENDRIK Hartog, Man \& Wife in America: A History 15 (2000). In such cases, the characteristic ideas underlying the "laboratory" metaphor — that the world had entered a new age of rapid and massive social change, that objective and experimental science offered the only effective method of dealing with that change, and that such science made general social progress possible - were absent. On the evolution of state social policies, see Susan M. Sterett, Public Pensions: Gender \& Civic Service in the States, 1850-1937 (2003). On another track, of course, the states had from the nation's beginning competed with one another in seeking economic development and comparative commercial advantages. 
begin employing it widely, and adopt the distinctive "laboratory" metaphor. That striking conceptual development was the product of Progressivism and its buoyant faith in science, expertise, and rational social improvement. ${ }^{147}$ The idea of the states as "laboratories" was entirely different, for example, from the eighteenthcentury view of Hamilton, Madison, David Hume, and John Adams that history contained the record of "experiments" that allowed "the politician or moral philosopher" to understand "the principles of his science." 148 It was distinct, too, from the founders' ideas that government under the Constitution would serve as a test for the possibility of republican self-government ${ }^{149}$ and that only an "actual trial" of the Constitution could reveal any "errors" in its design. ${ }^{150}$ Those eighteenth-century ideas shared the assumption that human nature and the principles of politics were unchanging and that the goal of "science" was to discover a balanced form of government that would allow "energetic" action while preserving individual liberties. In contrast, the idea of the states as "laboratories" sprang from profoundly different assumptions: that rapid and far-reaching changes were destroying an older social world and creating a new and radically different one, that novel methods and institutions were essential to meet the unprecedented disruptions and dangers

147. On the fascination of Progressives with science and expertise, see JAMEs T. Kloppenberg, Uncertain Victory: Social Democracy and Progressivism in European and American Thought, 1870-1920 (1986); Dorothy Ross, The Origins of American Social Science (1991); Samuel P. Hays, Conservation and the Gospel of Efficiency: The Progressive Conservation Movement, 1890-1920 (1959).

148. Richard B. Bernstein \& Kym S. Rice, Are We To Be a Nation: The Making of the Constitution, 120 (1987) (referring to Hume and Adams). For Hamilton, see The Federalist, No. 85, supra note 12, at 574 (quoting Hume on the need for "trials and experiments" before government can be brought "to perfection"). For Madison, see The Federalist, No. 38, supra note 12, at 234-39 (discussing historical examples of "experiments" in government).

149. E.g., The Federalist No. 1, supra note 12, at 3 (Alexander Hamilton) (“[T]he people of this country" would determine "whether societies of men are really capable or not of establishing good government from reflection and choice ....").

150. See, e.g., The Federalist No. 38, supra note 12, at 235 (James Madison) (arguing that the "plan of the convention" must be subjected to "an actual trial" before its defects can be known). Accord John Jay, An Address to the People of the State of New York, On the Subject of the Constitution, Agreed Upon at Philadelphia, the 17th of September, 1787 (1788), reprinted in 3 The Correspondence and Public Papers of John Jay, 17631826, at 294, 318 (Henry P. Johnston ed., 1971) (explaining that if "on experiment" the Constitution "should be found defective or incompetent," the people "may either remedy its defects, or substitute another in its room"). 
of a new industrial order, and that modern experimental science was capable of understanding the processes of social change, mastering complex new problems, and improving the general conditions of life for all people.

Given the distinctive origins and assumptions of the "laboratory" metaphor, it was no surprise that it was the Progressive activist Louis D. Brandeis who popularized it most widely. "There is a great advantage in the opportunity we have of working out our social problems in the detached laboratories of the different states," he counseled in 1912. With "the full benefit of experiments in the individual states," 151 reformers could design intelligent and effective laws establishing minimum wages, maximum hours for factory workers, compensation programs for industrial injuries, and a wide variety of other salutary public health and safety measures. After his successful argument before the Supreme Court in Muller v. Oregon, ${ }^{152}$ which upheld a state statute regulating the hours of female factory workers, Brandeis praised the law and portrayed the Oregon legislature as a methodical social scientist applying modern experimental methods to solve the problems of industrialism. ${ }^{153}$ When sitting on the Court in 1932, he articulated the idea it in what became its classic formulation. "It is one of the happy incidents of the federal system, that a single courageous State may, if its citizens choose, serve as a laboratory and try novel social and economic experiments without risk to the rest of the country." 154

The power of the metaphor grew out of the same Progressive faith in science and social reform that led Brandeis to recast Thayer's "rule of the clear mistake" in his effort to open the constitutional gates more widely to social reform efforts in the states. ${ }^{155}$ Given the idea's political use, then, it was also no surprise that Taft

151. Letter from Louis D. Brandeis to Mary E. McDowell (July 8, 1912), in 2 LETters of Louis D. Brandeis, 1907-1912: People's Attorney 639, 640 (Melvin I. Urofsky \& David W. Levy eds., 1972) [hereinafter Letter from Brandeis to McDowell] .

152. 208 U.S. 412 (1908).

153. Louis D. Brandeis, The Curse of Bigness: Miscellaneous Papers of Louis D. BRANDEIS 73 (1935).

154. New State Ice Co. v. Liebman, 285 U.S. 262, 311 (1932) (Brandeis, J., dissenting).

155. See, e.g., Maeva Marcus, Louis D. Brandeis and the Laboratories of Democracy, in Federalism and the Judicial Mind: Essays on American Constitutional Law and Politics 75-91 (Amy Turo et al. eds., 1992). 
rejected it so bluntly. Indeed, in launching his classic rejoinder in Truax v. Corrigan Taft responded directly to Brandeis himself, by countering the latter's brash dissent that dismissed the common-law rules of master and servant as "merely experiments in government" which "must be discarded when they prove to be failures." 156

With respect to federalism, moreover, the "laboratory" metaphor had dubious and even insidious implications. As Earl M. Maltz pointed out, it undermined, rather than supported, traditional ideas about the virtues of decentralization. Implicitly, the metaphor of laboratory experimentation challenged both the autonomy and diversity of the states by conceiving of their legislation "as a vehicle for eventually developing a national consensus on 'correct' social and economic policies" that demanded adoption nationwide. ${ }^{157}$ When Brandeis spoke of the states as laboratories for resolving social problems, he also spoke of identifying "the ultimate right solution of the problem."158 The idea behind the metaphor, then, was not only novel to the twentieth century but inconsistent with other "values" of American federalism.

Another quality of Brandeis's laboratory metaphor was even more revealing. It was a sometime thing. When the states passed statutes restricting non-economic rights involving free speech, he and many others who deployed it in defense of progressive legislation immediately objected, arguing that such state actions were unconstitutional. ${ }^{159}$ The states' "laboratory" function, in other words,

156. 257 U.S. 312, 353, 354-55 (1921) (Brandeis, J., dissenting). Taft was also responding to Holmes's separate dissent invoking the metaphor, but it was undoubtedly the progressive Brandeis who most stoked Taft's ire and provoked the Chief Justice to respond so directly. It was also Brandeis in the first place, most likely, who had inspired Holmes to write about "social experiments" as he did. See id. at 344 (Holmes, J., dissenting).

157. Earl M. Maltz, The Impact of the Constitutional Revolution of 1937 on the Dormant Commerce Clause - A Case Study in the Decline of State Autonomy, 19 Harv. J.L. \& Pub. POL'y 121, 127-28 (1995-96).

158. Letter from Brandeis to McDowell, supra note 151, at 639.

159. Brandeis rejected the "laboratory" metaphor, for example, when he joined the Court in its two earliest decisions that expanded substantive due process analysis to protect non-economic fundamental rights. Meyer v. Nebraska, 262 U.S. 390 (1923); Pierce v. Society of Sisters, 268 U.S. 510 (1925). Similarly, reflecting the same substantive orientation, liberal Justice Arthur Goldberg saw no relevance for the laboratory metaphor when he defended the Warren Court's broad incorporation doctrine against conservative attacks. Echoing Taft, he declared that "I do not believe that this [laboratory idea] includes the power to experiment with the fundamental liberties of citizens 
was not a substantive "value" but a pragmatic tool, an instrument whose desirability depended — as Taft had readily understood — on the nature of the experiment at issue. ${ }^{160}$ It was for that reason, in part, that the laboratory metaphor dropped from vogue almost immediately after World War II, when the idea of "social experiments" suddenly came to summon up images not of benevolent social reforms but of Nazi death camps and Stalinist labor colonies.

Finally, the idea of states as "laboratories" was not only an invention of the twentieth century but also a radical departure from the idea of states that dominated the ante-bellum era. Then, the laboratory idea was not only absent but anathema. States were regarded as clones of rival social systems, expected to remain loyal at all costs to the values and institutions of the labor system that spawned them. Along the Mason-Dixon line and into the battleground of the western territories, states were nothing so much as border fortresses, outposts protecting the counterpoised realms of free and slave labor. Calhoun fought to protect slavery in the District of Columbia, he announced, because the nation's capital constituted the "outworks" of the South. ${ }^{161}$ When the Kansas-Nebraska act voided the Missouri Compromise line in 1854 and created two potential new states, ${ }^{162}$ the result was "Bleeding Kansas," not a rational experiment in social policy but a free-fire zone of cultural imperialism, a stem-cell territory waiting to take on the characteristics of whichever region could impose its social and economic system. Missouri, the bordering slave state, became the base for pro-

safeguarded by the Bill of Rights.” Pointer v. Texas, 3809 U.S. 400, 410, 413 (1965) (Goldberg, J., concurring).

160. When the California legislature voted to legalize same-sex marriage in 2005, Republican state assemblyman Ray Haynes, an opponent of the measure, made the standard response: "Engaging in social experimentation with our children is not the role of the legislature." Showing rhetorical creativity, however, he not only rejected the "laboratory" metaphor (with its connotations of care, control, scientific method, and orderly progress) but substituted another metaphor (suggesting risk, uncertainty, foolishness, and ultimate ruin) more suitable to his purpose. "We are throwing the dice and taking a huge gamble," he declared, "and we are gambling with the lives and future of generations not yet born." Dean E. Murphy, Same Sex Marriage Wins Vote in California, N. Y. Times, Sept. 7, 2005, A14. Thus metaphor spawns metaphor, but the nature and limits of federalism remain ambiguous and contested.

161. Merrill D. Peterson, The Great Triumvirate: Webster, Clay, and CalHOUN, 260 (1987) (quoting John C. Calhoun).

162. See Fehrenbacher, supra note 64, at 152-77. 
slavery military incursions, while Lawrence, the territory's anti-slavery center, quickly became known throughout the North as "the Free State Fortress." 163

Thus, to see the states as "laboratories" was to see a federal system different from the one the founders had established and different from the one that existed through most of the nineteenth century. ${ }^{164}$ It was, in fact, to see a novel and distinctly twentiethcentury federalism. The Progressives' use of the "laboratory" metaphor illustrated the way that new generations infused new values and ideas into the complex structures of American federalism, and those who subsequently adopted the metaphor illustrated the way that later generations absorbed such changes while forgetting that they were, in fact, changes.

A third "value of federalism," the protection that decentralized government offered to distinctly "local" values and interests, suggested yet another problem. In the eighteenth century, and into the nineteenth, the states remained diverse geographical communities with their own relatively homogeneous populations and distinctive habits, attitudes, and traditions. ${ }^{165}$ "Virginia," Patrick Henry announced proudly during the ratification debates, "has certain scruples." 166 During the Revolutionary War Washington's army faced "overwhelming difficulties" because an "intense separatism" generated fierce "determination to keep local resources to defend [local] homes and towns," Daniel Boorstin wrote. ${ }^{167}$ "The very term 'American Revolution' propagates a wholly fictional sense of

163. Charles N. Glaab, Kansas City and the Railroads: Community Policy in the Growth of a Regional Metropolis 95 (1962).

164. This does not implicate the further serious question whether the states can and do, in fact, act as "laboratories." See Rubin \& Feeley, supra note 122, at 924-25; James A. Gardner, The "States-As-Laboratories" Metaphor in State Constitutional Law, 30 VAL. U. L. REv. 475 (1996).

165. By the mid-eighteenth century, growing trade and an expanding commercialized agriculture were beginning slowly to transform the colonial economies and multiply contacts with England and the rest of the world, and intercolonial contacts and cooperation also began to increase. As late as the 1760 s, however, such intercolonial cooperation was spotty and unreliable, and participation was still limited to a tiny fraction of the population. See generally Appleby, supra note 26.

166. Patrick Henry, Speeches of Patrick Henry, in The Anti-Federalist Papers and the Constitutional Convention Debates 199, 216 (Ralph Ketcham ed., 1986) [hereinafter The Anti-Federalist Papers].

167. Daniel J. Boorstin, The Americans: The Colonial Experience 362 (1958). 
national coherence not present at the moment," Joseph J. Ellis explained, and as late as 1789 "the states and regions comprising the new nation had no common history as a nation and no common experience behaving as a coherent collective."168 That colonial sense of separateness was the result of rural conditions, small and scattered populations, the slowness and difficulty of transportation and communication, and a social and political localism that gave little heed to the affairs of the other colonies. Moreover, when those localities did look outward, they looked toward England. ${ }^{169}$ As late as 1800, when Thomas Jefferson was elected president, ninety-six percent of the nation's population lived in small towns or rural areas, while only six cities claimed more than 10,000 inhabitants. ${ }^{170}$ When the founders drafted and ratified the Constitution, an "entrenched localism" was the "predominant factor" in American life. ${ }^{171}$

The ratification debates reflected those realities. For their part, the Anti-Federalists "looked to the Classical idealization of the small, pastoral republic where virtuous, self-reliant citizens managed their own affairs." 172 The "Federal Farmer" explained that "the state governments will possess the confidence of the people" because their agencies "will have a near connection, and their members an immediate intercourse with the people." ${ }^{173}$ Brutus made the same point. Only when a person was "a neighbor" with whom one was "intimately acquainted" would a person "commit his affairs into his hands with unreserved confidence."174 For their part, the Federalists generally accepted the same assumption, while

168. Joseph J. Ellis, Founding Brothers: The Revolutionary Generation 6, 11 (2000).

169. Walter T.K. Nugent, Structures of American Social History 59-60, 63-64, 79, 81-82 (1981).

170. Thomas Bender, Toward An Urban Vision: Ideas and Institutions in NineTeEnth Century America 3 (1975).

171. R. Kent Newmyer, John Marshall, Political Parties, and the Origins of Modern Federalism, in Federalism: Studies in History, Law, and Policy: Papers from the Second Berkeley Seminar on Federalism 17, 17 (Harry N. Scheiber \& Theodore Correl eds., 1988).

172. Ralph Ketchum, Introduction to The Anti-Federalist PAPERs, supra note 166, at 17.

173. The Federal Farmer, Letters From the Federalist Farmer II, reprinted in The Anti-Federalist Papers, supra note 166, at 267.

174. Essays of Brutus, No. IV, supra note 16, at 385. 
cleverly turning its significance. ${ }^{175}$ Madison used the predominance of localism to argue that the new central government would not be able to overpower the states. "[T] he first and most natural attachment of the people will be to the governments of their respective states," he explained. The "greater proportion of the people have the ties of personal acquaintance and friendship" with local officials, and therefore "the popular bias may well be expected most strongly to incline" toward them. ${ }^{176}$ Hamilton, cleverly but far more disingenuously, simply snuck an ambiguous new element onto the standard list of intimate acquaintances. "Where, in the name of common-sense," he asked, "are our fears to end if we may not trust our sons, our brothers, our neighbors, our fellowcitizens?" 177

In the decades following the Revolution, however, Americans "fundamentally altered their society and their social relationships," abandoning the assumption that in a proper society "most people were bound together by personal ties of one sort or another."178 Always a relatively mobile people, Americans increasingly spread out across the land, moving between farm and city, job and job, state and state. By the 1830s the average American appeared to Tocqueville as someone "always in a hurry" who "settles in a place from which he departs soon after so as to take his changing desires elsewhere." 179 Within barely a century of the founding, transportation and communication revolutions, expansion to the Pacific, industrialization and urbanization, and the influx of ethnically and religiously diverse immigrant groups had combined to transform American society and the way its people lived and thought. ${ }^{180}$ By

175. Sometimes the Federalists denied that distance would have a significant effect under the Constitution, and sometimes they argued that improved methods of transportation and communication would quickly develop and minimize the burdens of distance. See Rosemarie Zagarri, The Politics of Size: Representation in the United StATES, 1776-1850, at 94-95 (1987).

176. The Federalist, No. 46, supra note 12, at 305 (James Madison). Such strong local connections presented dangers, Madison warned, for "the members of the federal legislature will be likely to attach themselves too much to local objects." Id. at 307.

177. The Federalist, No. 29, supra note 12, at 180 (Alexander Hamilton).

178. Gordon S. Wood, The Radicalism of the American Revolution 6 (1991).

179. Alexis de Tocqueville, 2 Democracy in America, 512 (Harvey C. Mansfield \& Delba Winthrop eds. \& trans., Univ. of Chi. Press, 2000) (1835).

180. See generally Nugent, supra note 169; Riker, supra note 122, at 104-10. 
the mid-nineteenth century, if not before, the comfortable idea that Americans dealt with familiar neighbors known to their tightly-knit communities had given way to the unnerving idea that they were too often compelled to deal with strangers who were unknown and in many ways unknowable. The founders' classic image of social stability and the local citizen personally known to be virtuous had given way to Melville's disturbing image of pervasive social risks and uncertainties posed by an ever different but ever-reappearing "Confidence Man."181

In the process the authentically "local" in America - values, habits, ideas, and practices distinctive to specific place - weakened, disintegrated, and often disappeared, either blending into widely shared national attitudes or fading into the eccentric and peripheral. "Mobility, the challenge democracy set out to meet," Robert Wiebe noted, "turned out to be one of its greatest assets in unifying American society." 182 As Americans set out from their homes, the "first principles" of democratic government "slipped easily into their bags" and provided "a citizen's ticket that was good for admission to public life wherever they might go."183 Similarly, private organizations proliferated and spread across the land, facilitating the process of nationalization and unification. In 1760, excluding church and commercial organizations, fewer than forty local associations existed in the colonies, and not one was founded as a national organization. ${ }^{184}$ By the 1830 s there were more than thirteen hundred such associations, most with extensive interstate affiliations and many transformed into — or initially founded as national associations espousing openly national goals. ${ }^{185}$

181. Herman Melville, The Confidence Man: His Masquerade (Oxford Univ. Press 1984) (1857). "One consequence of modern life is the increased number of interactions among strangers; this may be part of the very essence of mobility. . . . $[\mathrm{M}]$ odern society has a feature almost completely lacking in simpler societies: dependence on strangers." Lawrence Friedman, The Republic of Choice: Law, Authority, and Culture 70, 72 (1990).

182. Robert H. Wiebe, Who We Are: A History of Popular Nationalism 71 (2002).

183. Id.

184. Theda Skocpol, Diminished Democracy: From Membership to Management in American Civil Life 31, 51 (2003).

185. Id. By the late nineteenth century almost two-thirds of all new associations were founded with national ambitions and national policies in mind. Id. at 50 . 
Equally important, some of the "local" values that were held most firmly in the eighteenth century - those involving race, religion, ethnicity, and the proper hierarchy of social deference - were subsequently repudiated by constitutional provisions, national legislation, Supreme Court rulings, and the development of a national culture and ideology of democracy. Far and away the most distinctive, deeply-embedded, and passionately defended "local" institution in America, after all, was slavery. As late as 1861 even Lincoln and the Republicans accepted the principle that "the proper division of local from federal authority" precluded the national government from abolishing the institution in the states where it existed. ${ }^{186}$ The Thirteenth Amendment, however, extinguished that "local" value. Similarly, other subjects often considered "local" — including marriage, divorce, child-rearing, and matters involving the health, safety, and morality of communities - came to be shaped by national laws, ${ }^{187}$ in some cases directly and in others indirectly through laws involving taxes, pensions, welfare, bankruptcy, and immigration. ${ }^{188}$ Indeed, the institution of marriage, which was often portrayed as a quintessentially "local" matter, ${ }^{189}$ provoked a series of vigorous debates about the desirability of unifying the nation's marriage laws when it repeatedly created practical problems involving interstate relations and the meaning of the Full Faith and

186. Abraham Lincoln, Address at Cooper Institute, in 3 The Collected Works of Abraham Lincoln 523 (Roy P. Basler ed., 1953). In his classic Second Reply to Hayne, Webster made the same point, declaring that suspicions of the South would never lead him "to overstep the limits of constitutional duty, or to encroach on the rights of others. The domestic slavery of the South I leave where I find it - in the hands of their own Governments. It is their affair, not mine.” Webster, in The Webster-Hayne Debate, supra note 47 , at 91 . "Northern politicians agreed with their southern counterparts that slavery was a local matter, beyond the reach of federal law." Peterson, supra note 161, at 257.

187. See Theda Skocpol, Protecting Soldiers and Mothers: The Political Origins of Social Policy in the United States 65, 107, 129, 145 (1992); Naomi R. Cahn, Family Law, Federalism and the Federal Courts, 79 Iowa L. Rev. 1073, 1106-11 (1994).

188. See Anita Bernstein, For and Against Marriage: A Revision, 102 Mich. L. Rev. 129, 146-48 (2003); Judith Resnik, "Naturally" Without Gender: Women, Jurisdiction, and the Federal Courts, 66 N.Y.U. L. REv. 1682, 1721-29 (1991).

189. The subject of marriage did not arise at the Philadelphia convention, and the framers of the Fourteenth Amendment almost unanimously disavowed any intention to address "women's issues," including marriage. Hendrik Hartog, Man \& Wife in America: A History 16-18 (2000); Nelson, supra note 66, at 136-38 (discussing Congress's refusal to address women's voting rights). 
Credit Clause. ${ }^{190}$ The late nineteenth century, moreover, brought national regulation in response to polygamy and the Mormon control of Utah, ${ }^{191}$ while the movement for gay rights in the late twentieth century spurred a vigorous campaign to extend national authority and constitutionalize the law of marriage, a campaign supported by many who claimed on other issues to be ardent supporters of decentralized government. ${ }^{192}$

While the well-being of their geographical homes remained vital to Americans, ${ }^{193}$ the "local" issues that absorbed them increasingly reflected geographically specific manifestations of problems

190. See, e.g. Hartog, supra note 189 , at 17-20, 32-39, 247-49, 258-82; Norma Basch, Framing American Divorce: From the Revolutionary Generation to the Victorians (1999); Judith Resnik, Categorical Federalism: Jurisdiction, Gender, and the Globe, 111 YALE L.J. 619 (2001).

191. See Late Corp. of the Church of Jesus Christ of Latter Day Saints v. United States, 136 U.S. 1 (1890); Sarah Barringer Gordon, The Mormon Question: Polygamy and Constitutional Conflict in Nineteenth Century America (2002). "The battle with the Mormons allowed the American legal system to arm itself with unusual power to enforce the nation's allegiance to monogamy. In a society increasingly obsessed by the character of family life, polygamy came to be seen as such a monumental menace to the nation's households that it encouraged an unparallelled federal intervention in the internal governance of a territory." Michael Grossberg, Governing the Hearth: Law and the Family in Nineteenth-Century America 125-26 (1985).

192. See Defense of Marriage Act, Pub. L. No. 104-99, 110 Stat. 2419; 28 U.S.C.S. 1738C (1996); S. J. Res. 30, 108 Cong., 2d Sess. (2004) stating that

No State, territory, or possession of the United States, or Indian tribe, shall be required to give effect to any public act, record, or judicial proceeding of any other State, territory, possession, or tribe respecting a relationship between persons of the same sex that is treated as a marriage under the laws of such other State, territory, possession, or tribe, or a right or claim arising from such relationship;

President George W. Bush, Statement Calling for a Constitutional Amendment Defining and Protecting Marriage, 40 Weekly Comp. Pres. Doc. 912 (2004), available as http:/ / frwebgate6.access.gpo.gov/cgibin/waisgate.cgi? WAISdocID=7299089377+0+0+ $0 \&$ WAISaction=retrieve.

193. The point is not that "local" conditions and controversies do not matter. Quite the contrary. They matter greatly, and it may well be that the "local" is almost all that does matter to most people most of the time. States, counties, cities, towns, and suburbs strive to gain control over many "local" matters, including the administration of "national" programs within their borders. See, e.g., Thomas J. Sugrue, All Politics is Local: The Persistence of Localism in Twentieth-Century America, in The Democratic Experiment: New Directions in American Political History, supra note 23, at 301-26; Matthew D. Lassiter, Suburban Strategies: The Volatile Center in Postwar American Politics, in The Democratic Experiment: New Directions in American Political History, supra note 23, at 327-49. The point, rather, is that the meaning and nature of the "local" has changed drastically over the past three centuries. To the extent that federalism protects the 
common to Americans across the nation - or at least common to the de facto nationwide socio-economic groups to which various local residents belonged. By the twentieth and twenty-first centuries the most pressing "local" issues seldom involved matters unique to a particular place; rather, they were geographically particularized formations of generic national problems involving jobs, crime, medical care, education, immigration, the price of oil, environmental degradation, public standards of morality, weapons of mass destruction, global economic competition, the threat of international terrorism, the content and orientation of national media, and recurring eruptions of racial, ethnic, and religiously-based conflicts. Critical to most of those concerns, moreover, were national pressures and policies or specific decisions about opening or closing local plants, clinics, offices, stores, military bases, housing projects, or other such facilities, decisions were made or influenced in almost every case by either the United States government or corporations chartered in other states or countries, corporations that were directing national and international business operations. At the beginning of the twenty-first century, then, the typical "local" issue seldom involved distinct values or habits peculiar to a specific location. Rather they usually involved widely shared problems and centered around the relationship between some specific geographical area and important interests rooted in other parts of the nation or world. A typical issue, for example, was whether people living in a particular geographical location could prevent Wal-Mart from opening a "supercenter" in their neighborhood 194

The transformation of the "local" had a dramatic effect on the idea of federalism. As the line between the "local" and the "na-

"local" in the contemporary world, it protects something quite different from what it protected in the eighteenth century.

194. See, e.g., William Burr, Zoning Board Recommends "No" on Planned Wal-Mart, TAmpa Trib., Nov. 3, 2004, at 4; David Pierson, Wal-Mart Supercenter Gets Foot in the Door, L.A. Times, Sept. 9, 2004, at A1; Kristina Smith, Opponents Weigh Next Move, News HerALD (Port Clinton, Ohio), Dec. 7, 2004, at 1A; Shannon Tan, Wal-Mart Backs Off Site at Busy Intersection, St. Petersburg Times (Fla.), Nov. 7, 2004, at 8. Another similar and typical "local" issue saw "hundreds of communities around the country" fighting national and international cell phone companies in efforts to prevent the erection of cellular transmission towers which residents found annoying, unattractive, and potentially dangerous to their health. Katie Hafner, First Come Cellphone Towers, Then the Babel, N.Y. Times, May 1, 2005, A1. 
tional" grew increasingly hypothetical and arbitrary in the lived experience of Americans, efforts to define its nature and specify its location increasingly became verbal formulations of largely imaginary divisions. ${ }^{195}$ Even some of federalism's most avid supporters readily conceded that the concept had lost its power to capture reality. "Where," Aaron Wildavsky asked, "is the philosopher's stone of federalism, the demarcation principle between central and state functions that would rationalize a division of labor within the American federal system?" His answer was blunt. "Nowhere." His reason compelling. "Every offer to specify what is local and what is national, I believe, will founder on these facts of life: every national activity has its local aspects and every local activity has a national perspective." 196

Thus, ideas about the "values of federalism" proved exceptionally problematic. New "values" were invented, and old ones given new content. More important, insofar as "values" remained unchanged, they did so as abstract concepts holding only uncertain and fluctuating connections with the existing federal system. ${ }^{197}$ While "values" such as protecting liberty, encouraging diversity, ensuring accountability, and promoting participation properly remained in the constitutional pantheon, they justified only one conclusion about the federal system: that divided government perhaps could, under the right circumstances, foster them. That conclusion said nothing, however, about how one struck the proper balance between the demands of the various "values" of federalism,

195. By the beginning of the twenty-first century the "local" versus "national" distinction was little more than a conclusory label serving obviously instrumentalist purposes, much like the distinction between "manufacturing" and "commerce" had been a century earlier. Compare, e.g., Kidd v. Pearson, 128 U.S. 1, 21 (1888) (holding that a state statute prohibiting manurfacure of intoxicating liquors did not violate the Commerce Clause) with Morrison, 529 U.S. at 617-18 (holding that the Commerce Clause does not grant congress the power to legislate civil remedies for victims of gender-motivated violence).

196. Aaron Wildavsky, Federalism \& Political Culture 68 (David Schleicher \& Brendon Swedlow eds., 1998). The complexity of life and the interrelationships among issues, Wildavsky concluded, meant "that no criterion of choice can be consistent in regard to all the legitimate political perspectives that may be brought to bear on them." Id.

197. See, e.g., Jane S. Schacter, Ely and the Idea of Democracy, 57 Stan. L. Rev. 737, 755-59 (2004) (summarizing a variety of empirical findings questioning the extent to which government is, or can be, held "accountable" by "the people"). 
whether and to what extent any particular level or branch of government was actually fulfilling those values, or how the relationships among the levels and branches could be adjusted to increase their likelihood of doing so. Like other questions about federalism, none of those could be answered in the abstract. Nor, of course, could any be answered from the text of the Constitution or the "original" intentions and understandings of the founders.

\section{Changing Ideas About the Nature of Federalism}

While the proffered "values of federalism" changed over the years, so did the very concept of "federalism" itself. Initially, the federal system was simply an expedient, a working compromise necessary to allow the founders to forge a new and more "energetic" central government. Unlike the principle of separation of powers, a structural device that the founders freely chose to utilize, the existence of separate states was a political reality - an historical fait accompli - that they were compelled to accept and challenged to overcome. Most of the founders, Edmund S. Morgan explained, "were convinced that unless they came up with an acceptable, and at the same time workable, scheme of national government, the union would dissolve." 198 Designed both to preserve and eliminate state "sovereignty," American constitutional federalism was unsettled and contested from the outset, and the uncertain lines between national and state powers that the founders vaguely sketched were limned in reality far more by custom and convenience than text or theory. ${ }^{199}$

The early operations of the federal system, moreover, were varied and uncertain, as individuals and groups considered its possibilities and staked out tentative positions on unanticipated issues. Sometimes the founders used national powers boldly and broadly - Hamilton's financial program, Washington's Neutrality Proclamation, Jay's Treaty, the Alien and Sedition Acts, Jefferson's Louisi-

198. Edmund S. Morgan, The Birth of the Republic, 1763-1789 134 (3d ed. 1992).

199. See, e.g., Toward a More Perfect Union: Writings of Herbert J. Storing 81 (Joseph M. Bessette ed., 1995); Rakove, supra note 145, at 168, 201; Murray Dry, AntiFederalism in The Federalist: A Founding Dialogue on the Constitution, Republican Government, and Federalism, in Saving the Revolution: The Federalist Papers and the AmeriCAN Founding 40 (Charles R. Kesler ed., 1987). 
ana Purchase, the Embargo and Non-Intercourse Acts, the beginnings of the "American System," and the decisions of the Marshall Court to identify only prominent examples. Sometimes, conversely, those same founders constrained national power sharply and insisted that state authority was broad and fundamental. Further, the constitutional views of the founders shifted as issues changed and their own positions in the national government strengthened or weakened. Jefferson's vigorous actions as president surely contradicted many of the positions he had taken in opposition to Federalist Party policies, ${ }^{200}$ and Madison's opposition to the first Bank of the United States in 1791 changed into support for the second Bank of the United States in 1816. ${ }^{201}$ From the first days of Washington's presidency, the founding generation demonstrated that it shared no determinate and comprehensive agreement on the nature of the federal system or the lines that divided national and state power. ${ }^{202}$

Over the decades, however, as the new governmental system proved successful and its practices grew relatively settled, commentators began to advance general theories about the nature of American federalism. The culture and politics of the nineteenth century gave rise to the idea that the Constitution ordained a system of "dual federalism," while developments of the twentieth century inspired the idea that it created a system of "cooperative federalism." The former assumed that the national government was one of limited and delegated powers and that the states were "independent" sovereigns with exclusive authority over clearly identifiable "local" matters. In theory, "dual federalism" preserved liberty and democ-

200. See, e.g., Bernstein, supra note 37, at 141-43, 145-47, 166-68; LeONARd W. LeVy, Jefferson and Civil Liberties: The Darker Side (1963); Joseph J. Ellis, American Sphinx: The Character of Thomas Jefferson 248-53 (1996). In 1798, for example, Jefferson scorned the practice of impeachment as nothing but a "formidable weapon for the purposes of a dominant faction." Letter from Thomas Jefferson to James Madison (Feb. 15, 1798), in 7 The Writings of Thomas Jefferson, supra note 41, at 202. By 1803, he was ready to support efforts to impeach federal judges, including a justice of the Supreme Court, who were staunch Federalists. See Ellis, supra note 30, at 71-72, 80-81.

201. McCoy, supra note 33, at 80-81. On Madison's changing views, see Rakove, supra note 145, at 339-65 (discussing Madison's changing views of Constitutional interpretation). See generally Elkins \& MCKITRICK, supra note 22, at 79-92, 133-61, 263-70.

202. Elkins \& McKitrick, supra note 22; Gordon S. Wood, The Creation of the AMERICAN Republic, 1776-1787 (1969); RAKove, supra note 145. 
racy by ensuring that each level of government was confined to its "separate sphere" and continually checked the expansionist efforts of the others. ${ }^{203}$ The idea of "cooperative federalism" conceived the system in a radically different manner. It assumed that federal power was elastic and that the various levels of government had overlapping interests and shared functions. In theory, "cooperative federalism" remained decentralized and democratic because no single governmental unit held exclusive power and because numerous gaps in governmental powers guaranteed wide areas of individual freedom. ${ }^{204}$ The idea of "dual federalism" assumed the existence of clear constitutional borders and their enforcement by the Supreme Court, while the theory of "cooperative federalism" relied on the existence of political parties and pressure groups to maintain the system's working boundaries. Both nicely reflected the dominant, values, practices, and politics of the centuries that inspired their formulation.

The labels served as both jurisprudential guides and ideological instruments. Those who opposed national action tended to invoke the theory of "dual federalism" to demonstrate that their views were consistent with the "authentic" federalism of the founders, while those who advocated expanded national action increasingly adopted the idea of "cooperative federalism" to demonstrate that "dual federalism" was inaccurate as historical description and out-

203. The classic account is Edward S. Corwin, The Passing of Dual Federalism, 36 VA. L. Rev. 1, 4 (1950). For a judicial statement, see Tarble's Case, 80 U.S. (13 Wall.) 397, 406 (1871).

204. Morton Grodzins, The American System: A New View of Government in THE United States (Daniel J. Elazar ed., Transaction Books 1984) (1966). Some scholars have argued that "cooperative" federalism was "the rule in the 19th century as well as the 20th.” Daniel J. Elazar, The American Partnership: Intergovernmental Cooperation in the Nineteenth Century United States 338 (1962). Accord Morton Grodzins, Centralization and Decentralization, in A Nation of States: Essays on the American System (R. Goldwin ed., 1963). Most, however, see "cooperative federalism" as a development rooted in the transformation of American society that began in the late nineteenth century. Harry N. Scheiber, American Federalism and the Diffusion of Power: Historical and Contemporary Perspectives, 9 U. Tol. L. Rev. 619, 622-35 (1978); Scheiber, supra note 127, at 692-711. For a time "the abstract, legalistic concept of 'dual federalism' had real-life meaning, a palpable presence in both the dynamics of legal process and the substantive content of the law." Id. at 705. On the importance of political parties in preserving decentralized government, see for example, Riker, supra note 122, at $101-04$. 
moded as constitutional prescription. ${ }^{205}$ In spite of disagreements, however, by the middle of the twentieth century few disputed that American government showed little resemblance to a system of "dual" federalism and considerable similarity to a more centralized type of "cooperative" - or, as some critics of centralization began to call it, "coercive" 206 - federalism.

Almost on cue, then, as the social and cultural dynamics of American politics were massively transformed after the 1960s and critics of post-New Deal liberalism sought more convincing grounds on which to condemn "cooperative federalism," responsive theories crystallized and rose to prominence. ${ }^{207}$ Rooted intellectually in an exceptional collection of works published within little more than a decade after 1951, ${ }^{208}$ theories of "competitive federalism" sprouted from the same revitalized interest in neo-classic economics that gave nearly simultaneous birth to such movements as "law and eco-

205. One of the most prominent advocates of the view that "cooperative federalism" characterized the nineteenth-century seemed to retain that view even as his politics changed in the late twentieth. See Daniel J. Elazar, American Federalism Today: Practice Versus Principle, in American Federalism: A New Partnership for the Republic 37-58 (Robert B. Hawkins ed., 1982).

206. E.g., John Kincaid, From Cooperative to Coercive Federalism, 509 Annals Am. Acad. of Pol. \& Soc. SCI. 139 (1990). For a response defending a later and modified theory of "cooperative federalism," see Daniel J. Elazar, Cooperative Federalism, in CoMpetition among States and Local Governments: Efficiency and Equity in American FederalISM 65-86 (Daphne A. Kenyon \& John Kincaid eds., 1991).

207. The fragmentation of the liberal "New Deal Order" is a complex story. See, e.g., The Rise and Fall of the New Deal Order 1930-1980 (Steve Fraser \& Gary Gerstle eds.,1989); Keith E. Whittington, Taking What They Give Us: Explaining the Court's Federalism Offensive, 51 Duke L.J. 477 (2001); Edward A. Purcell, Jr., Social Thought, 35 Am. Q. 80 (1983); Howard Gillman, Reconnecting the Modern Supreme Court to the Historical Evolution of American Capitalism, in The Supreme Court in American Politics: New Institutionalist Interpretations 235 (Howard Gillman \& Cornell Clayton eds., 1999).

208. The principal works drew on ideas that originated in the eighteenth century in the work of such writers as Adam Smith and the Marquis de Condorcet. See Kenneth Arrow, Social Choice and Individual Values (1951); James M. Buchanan \& Gordon Tullock, The Calculus of Consent: Logical Foundations of Constitutional Democracy (1962); Anthony Downs, An Economic Theory of Democracy (1957); Milton Friedman, Essays in Positive Economics (1953); Mancur Olson, The Logic of Collective Action: Public Goods and the Theory of Groups (1965); Ronald H. Coase, The Problem of Social Cost, 3 J.L. \& Econ. 1 (1960); Charles Tiebout, A Pure Theory of Local Expenditures, 64 J. Pol. EcON. 416 (1956). 
nomics" and "rational choice theory."209 Although variations abounded, the new theories of "competitive federalism" were both "positive" and normative. They began by assuming that individuals were self-seeking and utility-maximizing actors with highly varied preferences and that the proper function of government was to protect their freedom to seek satisfaction of those diverse preferences. Federalism was highly desirable, the argument ran, because it entailed a multitude of relatively equal and geographically limited governments, a structural condition that compelled them to compete for citizens by structuring attractive "packages" of costs and benefits. That structure, in turn, enabled individuals to satisfy their preferences more fully by freely selecting their homes from an extensive and highly varied menu of jurisdictions. Consequently, the argument concluded, it was essential to preserve many local governmental units, ensure that individuals retained the right to "exit" jurisdictions and move to others, and keep the powers of the central government limited so that it would not be able to suppress competition and enforce dysfunctional uniformities among the states. ${ }^{210}$ In the last quarter of the twentieth century those ideas spread widely and attracted increasingly strong interest and support.211

209. See, e.g., James M. Buchanan, Constitutional Economics 60-61 (1989); Barry R. Weingast, Political Institutions: Rational Choice Perspectives, in A New Handbook of PoLiticAl SCIENCE 167-90 (Robert E. Goodin \& Hans-Dieter Klingemann eds., 1996).

210. For examples of relevant work, see James M. Buchanan, Explorations into Constitutional Economics (1989); Buchanan, supra note 209; Robert D. Cooter, The Strategic Constitution (2000); Thomas R. Dye, American Federalism: Competition Among Governments (1990); Albert O. Hirschman, Exit, Voice, and Loyalty: Responses to Decline in Firms, Organizations, and States (1970); Dennis C. MuelLer, Constitutional Democracy (1996); Jonathan R. Macey, Federal Deference to Local Regulators and the Economic Theory of Regulation: Towards a Public-Choice Explanation of Federalism, 76 VA. L. Rev. 265 (1990); Michael W. McConnell, Federalism: Evaluating the Founders' Design, 54 U. CHI. L. REv. 1484, 1491-1500 (1987); McGinnis \& Somin, supra note 119; Barry R. Weingast, The Economic Role of Political Institutions: Market-Preserving Federalism and Economic Development, 11 J.L. Econ. \& Org. 1 (1995). See generally Philip P. Frickey and Steven S. Smith, Judicial Review, the Congressional Process, and the Federalism Cases: An Interdisciplinary Critique, 111 YALE L.J. 1707 (2002).

211. The theories also drew widespread criticisms. See Vicki Been, "Exit" As a Constraint on Land Use Exactions: Rethinking the Unconstitutional Conditions Doctrine, 91 Colum. L. Rev. 473 (1991); Truman F. Bewley, A Critique of Tiebout's Theory of Local Public Expenditures, 49 Econometrica 713 (1981); Don Herzog, Externalities and Other Parasites, 67 U. CHI. L. Rev. 895 (2000); Robert P. Inman and Daniel L. Rubinfeld, The Judicial Pursuit of Local Fiscal Equality, 92 Harv. L. Rev. 1662 (1979); Jonathan Rodden \& Susan RoseAckerman, Does Federalism Preserve Markets? 83 VA. L. Rev. 1521 (1997); Stewart, supra 
Like the theories of "dual" and "cooperative" federalism that preceded it, the idea of "competitive federalism" readily served ideological purposes. Michael S. Greve, for example, a leading scholar at the conservative American Enterprise Institute, castigated "cooperative federalism" as "a rotten idea" while elaborating the contrasting virtues of "competitive" or "market-preserving" federalism. ${ }^{212}$ Yet, he did not accept all competition and markets as good. He bitterly attacked the Court's decision in Erie Railroad Co. $v$. Tompkins, ${ }^{213}$ even though it abolished the centralized national common law of Swift $v$. Tyson ${ }^{214}$ and directed the federal judiciary to enforce the varied common law rules of the separate states. Although Erie seemed like "a profederalism decision," Greve argued, it was actually "the opposite" because "parochial state courts" used their power to encourage the "systematic exploitation of out-of-state corporations in franchise disputes and, most egregiously, in products liability litigation." Similarly, Greve indicted "plaintiffs' lawyers" on the ground that they tended to "shop" among the states "for a hospitable court and jury" that would "sock it to out-of-state defendants." 215 Thus, the "competitive" right of states to establish their own distinctive menus of values and laws had sharp limits, as did the citizens' right to "exit" one jurisdiction to find in others more attractive "packages" of legal rules to better satisfy their preferences. ${ }^{216}$

note 121. More general criticisms of the economic analysis and public choice theory are numerous. See, e.g., Amartya Sen, Rationality and Freedom (2002); Jerry L. Mashaw, Greed, Chaos, \& Governance: Using Public Choice to Improve Public Law (1997); Donald P. Green \& Ian Shapiro, Pathologies of Rational Ghoice Theory: A Critigue of Applications in Political Science (1994).

212. Michael S. Greve, Against Cooperative Federalism, 70 Miss. L.J. 557, 559 (2000). See Michael S. Greve, Real Federalism: Why It Matters, How It Could Happen (1999).

213. 304 U.S. 64 (1938).

214. 41 U.S. (16 Pet.) 1 (1842).

215. Michael S. Greve, Laboratories of Democracy: Anatomy of a Metaphor, 6 A.E.I. FEDERALIST OUTLOOK 5-6, http://www.federalismproject.org/outlook/5-2001.html (last visited Feb. 23, 2006).

216. Greve and many other "competitive federalism" proponents accept limitations on states when state actions create "externalities," that is, when they impose costs on other states or on out-of-state residents. Theories of "competitive federalism," however, also rely on the availability of "exit rights," a device whose very nature is to create "externalities." "Exit rights," that is, function to allow states to adopt policies to induce "undesired" types of residents (however a state might conceive of such a category) to move to 
Like theories of "dual" and "cooperative" federalism, those of "competitive federalism" received much, if not most, of their specific content and direction from their advocates' social, political, and ideological commitments. ${ }^{217}$ Most commonly and pointedly, particular formulations of "competitive federalism" were shaped by and drew their strongest support from social and economic groups hostile to national regulation and especially from those who rejected the policies and programs associated with New-Deal and post-New-Deal liberalism. ${ }^{218}$ Indeed, while ostensibly securing such classic "values of federalism" as diversity, variety, and local autonomy, the theories actually helped pave the way for the increasingly dominant and homogenizing forces of a booming new international market economy. Their appearance and use in the late twentieth century exemplified once again the way in which theories of federalism emerged from the processes of social change and reflected the ideas, values, and challenges of new generations confronting new historical contexts and new political alignments. ${ }^{219}$ As

other states while attracting "desired" types of residents (however conceived) away from other states. Movement in either direction could impose "externalities" on other states and their residents. Thus, an analysis of "externalities" is, by itself, inadequate to identify situations when limitations on state actions are proper.

217. See, e.g., Jules Coleman, Markets, Morals, and the Law (1998). Contemporary debates over stem cell research illustrate both the reality of state competition and some of the substantive policy judgments necessary to evaluate its desirability and results. See, e.g., Sheryl Gay Stolberg, In Rare Threat, Bush Vows Veto of Stem Cell Bill, N.Y. Times, May 21, 2005, at A1; Nicholas Wade, Stem Cell Researchers Feel the Pull of the Golden State, N.Y. Times, May 22, 2005, at A24. Needless to say, there was substantial variety among advocates of "competitive federalism" in the de facto sources of their ideas, the specific policy conclusions they drew, and the political and social goals they sought to achieve. Some, for example, urged a relatively strong role for the national government in limiting the states. E.g., McGinnis \& Somin, supra note 119, at 89. For an interesting comparative view, see, for example, Fiscal Federalism (Mark Krasnick ed., 1986) (discussing problems and proposals relating to federalism in Canada).

218. The theory also reflected the dramatic economic and political changes that accelerated in the last quarter of the twentieth century as a response to the pressures of globalization. See, e.g., Neil Brenner, New State Spaces: Urban Governance and the Rescaling of StateHood (2004) (analyzing changes in Europe since the 1960s).

219. Liberals responded with alternate economic theories. One, for example, termed a "functionalist" approach, proposed that federalism worked most efficiently when state and local governments concentrated on basic public services and programs designed to encourage economic development while the national government focused on programs of social welfare and economic redistribution. "For the most part I find the direction of change to be consistent with functional theory," one political scientist concluded in 1995. "Each level of government is increasingly focused on the policy 
Lawrence Friedman wrote, over the course of more than two centuries the "culture of federalism," like "the reality of federalism," had been "drastically altered." 220

Indeed, the spread of "competitive federalism" theories illustrated just how "drastically altered" that culture and reality had become, for those theories were noticeably different from the major theories that had preceded them. Both "dual" and "cooperative" federalism purported to be rooted in the Constitution and derived from its provisions. "Competitive federalism," in contrast, rested on an analogy to an extraneous economic theory. Although its advocates maintained that the idea of "competitive federalism" was consistent with the Constitution, they also commonly acknowledged that it was neither explicitly mandated by the Constitution nor, as a factual matter, derived from it. ${ }^{221}$ Thus, "competitive federalism"

arena in which it has the greatest competence." PAul E. Peterson, supra note 128, at 50. See also id. at 185-95. Among the critical factors were the pressures of both human and capital mobility, competition among states and localities, economies and diseconomies of scale, and the variety of fiscal and other disparities that distinguished different areas in the country. "Quite apart from political developments in Washington, economic forces in society are forcing each level of the federal system to concentrate on issues within its area of competence." Id. at 83-84. For another effort to adapt federalism principles to the support of liberal or progressive ends, see Denise C. Morgan \& Rebecca E. Zietlow, The New Parity Debate: Congress and Rights of Belonging, 73 U. CIN. L. REV. 1347 (2005).

220. Lawrence M. Friedman, American Law: An Introduction 126 (1984). Friedman defined "legal culture" to mean "the ideas, attitudes, values, and opinions about law held by people in a society." He continued: "The assumption is that these ideas and attitudes influence legal behavior, especially the level of demands placed on the legal system. Legal culture, then, is a 'network of values and attitudes . . which determines when and why and where people turn to law or government or turn away.' It is thus the immediate source of legal change, whatever the ultimate source may be." LAWRENCE M. Friedman, Total Justice 31-32 (1994) (1985).

221. Richard Epstein, for example, acknowledged that critical elements of the economic analysis of federalism were not part of "the original constitutional plan" and "must be regarded as a modern reinterpretation." Richard Epstein, Exit Rights Under Federalism, 55 Law \& Contemp. Probs. 147, 150 (1992). While economic theorists sometimes attempted to link their ideas to traditional legal sources, especially to Madison's Federalist essays, they usually admitted that the connections were indirect, general, and highly selective (limited, for example, to such common and unexceptionable ideas as the self-seeking nature of human beings and the dangers of overly centralized government). See, e.g., id. at 148 (the Federalist presented some themes "familiar" to competition theorists); John Kincaid, The Competitive Challenge to Cooperative Federalism: A Theory of Federal Democracy, in Competition Among States and Local Governments: EffiCiency and EQuity in American Federalism 87, 88 (Daphne A. Kenyon \& John Kincaid eds., 1991) (noting that ideas in the Federalist may support but do not "land squarely on 
reflected the assumptions of its time in yet another way. It implicitly accepted the proposition that the nation's system of constitutional federalism was not for the most part shaped and directed by the Constitution itself but by values, theories, and assumptions that lay beyond the document's provisions.

\section{Changing Ideas About the Nature and Meaning of the Constitution}

Finally, on the broadest level, for over two hundred years shifts in cultural and intellectual assumptions slowly changed the way lawyers, judges and the educated public thought about law, the Constitution, and the operations of the federal system. The rise and spread of utilitarianism, naturalism, positivism, and relativism undermined many traditional legal and moral ideas. At the same time, philosophical skepticism, pragmatism, cognitive indeterminism, and later "postmodernism" deepened doubts about the human capacity to know while highlighting the seemingly infinite malleability of words, sounds, symbols, and images. As the ever more inventive and influential professions of advertising, public relations, and political consulting rose to prominence in the twentieth century, they confirmed the scope of that malleability and magnified the reasons for skepticism about ever-growing portions of public discourse. Together, those forces undermined many previously shared cultural understandings and inspired ever more audacious efforts to exploit the nation's crumbling consensus on meanings and values. Such developments implicitly and sometimes explicitly challenged the basic Enlightenment assumptions that underwrote the very idea of a written constitution. ${ }^{222}$

dual, cooperative, or competitive federalism”). Although Judge Frank H. Easterbrook called Madison "the progenitor of modern public choice theory," he acknowledged that the basic insight of "competitive federalism" was one that Madison "anticipates, without quite articulating." Frank H. Easterbrook, The State of Madison's Vision of the State: A Public Choice Perspective, 107 Harv. L. Rev. 1328, 1333 (1994). Thomas R. Dye discounted constitutional considerations: "Most debates over federalism are only lightly camouflaged debates over policy." Dye, supra note 210, at 184.

222. See generally Neil Duxbury, Patterns of American Jurisprudence (1995); Laura Kalman, The Strange Career of Legal Liberalism (1996); Gary Minda, Postmodern Legal Movements (1995); John Henry Schlegel, American Legal Realism and Empirical Social Science (1995); Anthony Sebok, Legal Positivism in AmeriCAN JURISPRUDENCE (1998). 
Ideas about the nature of the Constitution itself also changed. ${ }^{223}$ Eighteenth-century Newtonian assumptions led the founders to see the Constitution as a machine both powered and held in check by the forces of ambition, but that conception gave way in the nineteenth century to evolutionary assumptions that understood the Constitution as a "living" organism adapting to a changing social environment.224 Woodrow Wilson maintained in 1885 that the "chief strength" of the Constitution was its "elasticity and adaptability," for any "governmental system would snap asunder a constitution which could not adapt itself to the new conditions of an advancing society." 225 That adaptive process, Wilson reaffirmed two decades later, created a "national consciousness" that drove "a slowly progressive modification and transfer of functions as between the States and the federal government along the lines of actual development."226 In the early twentieth century many Progressives embraced the idea of a "living" Constitution in their efforts to combat the conservative federal judiciary, ${ }^{227}$ and by mid-century it had become a widely-shared idea, ${ }^{228}$ especially popu-

223. See Kammen, supra note 57 , at 17.

224. Howard Gillman, The Collapse of Constitutional Originalism and the Rise of the Notion of the "Living Constitution" in the Course of American State-Building, 11 STUdies IN Aм. Pol. Dev. 191 (1997).

225. Wilson, supra note 55, at 8-9. The Constitution adapted itself to those new conditions not for the most part by formal amendment but by judicial decision. "The character of the process of constitutional adaptation depends first of all upon the wise or unwise choice of statesmen, but ultimately and chiefly upon the opinion and purpose of the courts," Wilson explained. "The chief instrumentality by which the law of the Constitution has been extended to cover the facts of national development has of course been judicial interpretation, - the decisions of the courts." He then added the key legitimating qualification. "By legitimate extension I mean extension which does not change the character of the federal power, but only its items, - which does not make new kinds but only new particulars of power. Facts change and are taken care of, but principles do not change." WiLson, supra note 56, at 193.

226. WILSON, supra note 56, at 194.

227. "Our Constitution is not a strait-jacket," Brandeis wrote. "It is a living organism" that was "capable of growth — of expansion and of adaptation to new conditions." It was that very capacity for adaptation that explained why "it has endured as the fundamental law of an ever-developing people." Bickel, supra note 88, at 107. Accord Herbert Croly, The Promise of American Life 269 (Ne. Univ. Press, 1989) (1909).

228. The idea was not limited to "liberals." Traditional conservatives, in contrast to ideologically driven activists who claimed the label "conservative," often accepted the idea. Justice John M. Harlan, for example, agreed that "a living thing" - the nation's historical tradition - gave the Due Process Clause its meaning. "A decision of this 
lar among the liberal heirs of Progressivism ${ }^{229}$ and increasingly disputed at century's end by their adversaries. ${ }^{230}$

From the middle of the twentieth century on, and especially in the wake of the New Deal and Brown v. Board of Education, ${ }^{231}$ Americans struggled with the challenge of reconciling the undeniable facts of social and legal change with traditional jurisprudential ideas about the nature and purpose of a written Constitution. While theories proliferated, none seemed able to command substantial, let alone majority, support. Scholars and judges opposed to the liberal decisions of the Warren Court, for example, revived theories of "originalism" 232 which, they claimed, would provide clear norms and authoritative interpretations of the Constitution. Their conclusions often varied among themselves, ${ }^{233}$ however, and their methods raised grave analytical problems. One was the difficulty of identifying any clear and coherent "original" meaning on most specific issues; a second was the fact that whatever "original" meanings could be reliably ascertained seemed to provide little unambiguous or undisputed direction on contemporary controversies; a third was the spreading recognition that any authoritative guidance attributed to "original" meanings depended in large part on the level of generality at which interpreters chose to construe

Court which radically departs from [that living tradition] could not long survive, while a decision which builds on what has survived is likely to be sound." Poe v. Ullman, 367 U.S. 497, 542 (1961) (Harlan, J., dissenting).

229. E.g., Bruce Ackerman, We the People: Foundations 35-37 (1991); Tushnet, supra note 112, at 191 (1999).

230. E.g., William H. Rehnquist, The Notion of a Living Constitution, 54 TEx. L. Rev. 693 (1976).

231. 347 U.S. 483 (1954).

232. "Originalist" theories may claim as their foundation, inter alia, the "intent" of those who drafted or ratified the Constitution, the collective "understanding" those parties shared about the Constitution's meaning, or the "objective meaning" that the document's text conveyed to reasonable persons at the time.

233. The idea of construing the Constitution in light of the "original" intent or "understanding" of the founders was a thoroughly traditional method of judicial reasoning capable of serving a variety of purposes. Chief Justice John Marshall used it in McCulloch, 17 U.S. (4 Wheat.) 316, to justify expansive national power, for example, while Chief Justice Roger Taney used it in Dred Scott, 60 U.S. (19 How.) 393, to justify expansive state power. For examples of contemporary variations, see, for example, Ronald Dworkin, A Matter of Principle 34-57 (1985); Antonin Scalia, A Matter of Interpretation: Federal Courts and the Law (1998); Randy E. Barnett, An Originalism for Nonoriginalists, 45 Loy. L. REv. 611 (1999); Christopher L. Eisgruber, Early Interpretations $\mathcal{E}$ Original Sin, 95 Mich. L. Rev. 2005 (1997). 
those meanings. ${ }^{234}$ Originalism, in other words, although commonsensical and widely accepted as a general idea, was simply inadequate as a sole, or even primary, method of interpreting the Constitution. Its practical use, moreover, often opened constitutional interpretation to a range of potentially arbitrary and discretionary judgments. Beyond those analytic problems, finally, loomed the embarrassing fact that, as a practical political matter, originalist theories were used primarily as purposeful instruments of constitutional change and doctrinal innovation. ${ }^{235}$ Originalism was the natural tool of those who sought justifications for overthrowing existing doctrines, precedents, and practices.

The revitalization of originalism in the last quarter of the twentieth century highlighted rather than resolved the problems of constitutional interpretation. It demonstrated that a deep and sincere conviction that constitutional government and a "rule of law" required clear, determinate, and established norms was simply not sufficient to produce clear, determinate, and established norms. Indeed, originalism as a sole, or even primary, guide seemed likely to exacerbate the problems of constitutional uncertainty. To the extent that one ignored the evolutionary development of American federalism and discarded the innumerable markers and guides that

234. "Originalism" has been subject to a variety of criticisms. See, e.g., H. Jefrerson Powell, A Community Built on Words: The Constitution in History and Politics 4 (2002); Michael C. Dorf, Recipe for Trouble: Some Thoughts on Meaning, Translation, and Normative Theory, 85 Geo. L. Rev. 1857 (1997); Henry Paul Monaghan, Doing Originalism, 104 Colum. L. Rev. 32 (2004).

235. On the use of "originalism" as a method of justifying constitutional innovation, see Alfred H. Kelly, Clio and the Court: An Illicit Love Affair, 1965 Sup. Ct. Rev. 119. The writings of Felix Frankfurter and Clarence Thomas illustrate the standard pattern. Frankfurter, who strongly supported the New Deal, argued that narrow late nineteenthcentury interpretations of the Commerce Clause which blocked the New Deal conflicted with the true meaning of the clause as set out by the Marshall Court. Those later and narrower doctrines, he maintained, should be abandoned in favor of the earlier and truer interpretations. Felix Frankfurter, The Commerce Clause under MarShall, TANEY AND Waite (1937). Thomas, an advocate of the anti-New Deal values of the post-Reagan Republican coalition, claimed that the post-1937 decisions which validated the New Deal and overturned the narrow late nineteenth-century interpretations conflicted with the early decisions of the Marshall Court. The later and broader proNew Deal decisions, he maintained, should be overturned or narrowed substantially. Lopez, 514 U.S. at 549, 584, 601 (Thomas, J., concurring). For Justice Thomas's interest in making substantial changes in constitutional law, see Saenz v. Roe, 526 U.S. 489, 521 (1999) (Thomas, J., dissenting). 
its history had generated, one simply cast aside much of the nation's invaluable and hard-earned political, social, and moral wisdom. ${ }^{236}$ To the extent that one attempted to replace that national experience with preemptive claims of some untempered originalism, moreover, one expanded the realm of discretion in constitutional interpretation and multiplied the opportunities for infusing it with the personal, subjective, and ideological. Efforts to apply the approach consistently as a sole or primary guide demanded the impossible and promised to lead not only to continual compromise but also to continual pretense. ${ }^{237}$

In truth, originalism had failed from the beginning to produce clear and determinate norms on many issues, including the nature and limits of American federalism. Hamilton and Madison quickly fell out over the constitutional relationship between nation and states, as, in fact, did the entire founding generation. As early as 1793, for example, the Court issued its first major ruling on federalstate relations in Chisholm v. Georgia, ${ }^{238}$ a decision that was particularly revealing because it followed closely on the heels of ratification, raised a fundamental question of federal-state relations, and came from a five-Justice Court made up quite literally of nothing but the most authentic of "founders." The four justices in the majority included a Chief Justice who had been one of the three authors of the Federalist, a second justice who had presided over his state's ratifying convention, and two justices who had served as delegates to both their states' ratifying conventions and the Philadel-

236. Thus, there is nothing intrinsically "conservative" about "originalism." It is simply a method, useful for certain purposes and on certain issues. If purportedly used as a sole or even dominant guide, it can easily support profound misjudgments and radical or disruptive innovations.

237. For examples of the inadequate nature of "originalism" and its use as a political instrument, see Bork, supra note 20, at chs. 7-8, and Randy E. Barnett, Restoring the Lost Constitution: The Presumption of Liberty (2004), and the critiques of the two books in, respectively, Ronald Dworkin, Freedom's Law: The Moral Reading of the American Constitution, ch. 14 (1996), and Steven G. Calabresi, The Originalist and Normative Case Against Judicial Activism: A Reply to Professor Randy Barnett, 103 Mich. L. REv. 1081 (2005). For a reluctant acknowledgment of the severe limitations that constrain "originalism" by a scholar particularly sympathetic to the approach in theory, see Monaghan, supra note 234.

238. 2 U.S. (2 Dall.) 419 (1793). The issue was whether the national courts could hear suits for money due against states brought by citizens of other states. 
phia Constitutional Convention of 1787 itself. ${ }^{239}$ Yet the fifth justice, equally an authentic "founder" who had led the fight for the Constitution in his own state's ratifying convention, disagreed with them. ${ }^{240}$ Even more striking, a good many others — including more authentic founders - also disagreed, and within a bare five years they secured the adoption of a constitutional amendment that overturned the decision. ${ }^{241}$ Were four out of five "founders" simply wrong in Chisholm? Unlikely. More importantly, such a question is unhelpful and misleading. The episode most likely demonstrated, as John V. Orth concluded, that some founders disagreed with other founders and that the remainder - the overwhelming majority - had, until the specific question at issue arose, simply "given the matter no thought at all." ${ }^{42}$ There was, in other words, simply no "original understanding" on the issue.

Another factor, too, was surely involved in Chisholm and its repudiation. As the founders themselves recognized so keenly, by 1790s — only a few bare years after ratification — many things had already changed, and changed quite substantially. ${ }^{243}$

As subsequent controversies about federalism arose, moreover, "originalism" continued to play a similarly inconclusive, contested, and partisan role. In their debate over the constitutionality of the Bank of the United States in 1819, for example, both John Marshall and Spencer Roane avidly embraced originalism and pleaded their fidelity to the authentic Constitution of the founders. Marshall proclaimed that those, like Roane, who rejected his view, were animated by "unfounded jealousies" and "deep-rooted and vindic-

239. The Justices were, in order of reference, John Jay (New York), William Cushing (Massachusetts), John Blair (Virginia), and James Wilson (Pennsylvania). John V. Orth, The Judicial Power of the United States: The Eleventh Amendment in AmerICAN History 12, 22 (1987).

240. ORTH, supra note 239, at 22. The dissenting Justice was James Iredell (North Carolina). Id. at 12.

241. U.S. Const. amend. XI (1798).

242. ОRтн, supra note 239, at 28.

243. See e.g., Elkins \& McKitrick, supra note 22, at 263-70; Maeva Marcus \& Natalie Wexler, The Judiciary Act of 1789: Political Compromise or Constitutional Interpretation?, in Origins of the Federal Judiciary: Essays on the Judiciary ACt of 178913 (Maeva Marcus ed., 1992). 
tive hate."244 Roane announced that anyone who accepted Marshall's view "must be a deplorable idiot." 245

\section{Conclusion: Searching for the Mandates of Constitutional Federalism}

This essay has suggested some of the ways in which America federalism and our basic assumptions about its nature have changed over the centuries. When we study the federal system, it suggests, we are examining an evolving phenomenon, and we are doing so on the basis of concepts, assumptions and criteria that are themselves changing. Analysis thus becomes highly uncertain, and the idea of "constitutional federalism" — that is, federalism as a directive constitutional norm - becomes deeply problematic.

The inability of originalism to furnish clear and determinate constitutional norms is, of course, hardly a failing unique to that approach. Indeed, alternative approaches based on text, structure, history, precedent, convenience, and philosophy present their own particular problems, and few if any judges or commentators attempt to use any one of those methods exclusively or even consistently. ${ }^{246}$ The inadequacy of originalism, however, surely supports the proposition that the ambiguous and pliable nature of American federalism is hardly the result of abandoning its purportedly authoritative guidance. Rather, the normative problem of federalism arises from the combination of two paramount and quite different factors: one, the incomplete, ambiguous, and ambivalent nature of American constitutional federalism itself; the other, the relentless and disruptive processes of historical change, the diverse values and conflicting interests that ineluctably divide human beings, and the nearly infinite diversities that have both constituted and fragmented the American people over the centuries.

244. John Marshall, A Friend of the Constitution, Essay No. 1, in John Marshall's Defense of McCulloch v. Maryland, supra note 41, at 155.

245. See Roane, Hampden, Richmond EnQuirer, June 11, 1819, reprinted in John Marshall's Defense of McCulloch v. Maryland, supra note 41, at 106, 110.

246. For a discussion of some of the varied methods of constitutional interpretation, see Harry H. Wellington, Interpreting the Constitution: The Supreme Court and the Process of Adjudication (1990); Philip Bobbitt, Constitutional InTERPREtation 64-108 (1991); Richard H. Fallon, Jr., A Constructivist Coherence Theory of Constitutional Interpretation, 100 HaRv. L. REv. 1189 (1987). 
The problem, moreover, is further compounded by the sheer complexity, not to say perversity, involved in honest efforts to remain faithful to the Constitution's federal structure. Looking back over some four decades devoted to studying the founding era, Gordon Wood captured one of the special ironies that marked efforts to remain faithful to the American Revolution's principles of republicanism, a complexity that equally marks efforts to remain faithful to the Constitution's principles of federalism. "It was not that there were simply new kinds of people and new social groups emerging that required new values and new justifications for their behavior," Wood wrote. It was "also that circumstances often compelled those who wished to remain loyal to republican values to challenge and to subvert those values." 247 To recognize that perplexing, if partial, truth is to recognize one of the crucial complexities of American constitutional federalism. It is also to recognize the critical importance of understanding exactly how and why the nation's constitutional system evolved over the centuries, and why it will continue to do so.

247. Gordon S. Wood, Preface to the 1998 Edition of The Creation of the American Republic, 1776-1787 supra note 202, at xii. See Adrian Vermeule, Hume's Second-Best Constitutionalism, 70 U. CHI. L. Rev. 421 (2003) (suggesting that an "irreversible departure" from constitutional design may require other "violations" of constitutional design to best maintain the original constitutional purpose). 